\title{
Adaptation of Forest Trees to Rapidly Changing Climate
}

\author{
Joanna Kijowska-Oberc ${ }^{1, *}{ }^{\oplus}$, Aleksandra M. Staszak ${ }^{2}{ }^{-}$, Jan Kamiński ${ }^{1}$ and \\ Ewelina Ratajczak ${ }^{1, * \mathbb{D}}$ \\ 1 Institute of Dendrology, Polish Academy of Sciences, Parkowa 5, 62-035 Kornik, Poland; \\ jan_kaminski616@onet.pl \\ 2 Laboratory of Plant Physiology, Department of Plant Biology and Ecology, Faculty of Biology, University of \\ Bialystok, Ciolkowskiego 1J, 15-245 Bialystok, Poland; a.staszak@uwb.edu.pl \\ * Correspondence: joberc@man.poznan.pl (J.K.-O.); eratajcz@man.poznan.pl (E.R.)
}

Received: 25 November 2019; Accepted: 19 January 2020; Published: 21 January 2020

\begin{abstract}
Climate change leads to global drought-induced stress and increased plant mortality. Tree species living in rapidly changing climate conditions are exposed to danger and must adapt to new climate conditions to survive. Trees respond to changes in the environment in numerous ways. Physiological modulation at the seed stage, germination strategy and further development are influenced by many different factors. We review forest abiotic threats (such as drought and heat), including biochemical responses of plants to stress, and biotic threats (pathogens and insects) related to global warming. We then discus the varied adaptations of tree species to changing climate conditions such as seed resistance to environmental stress, improved by an increase in temperature, affinity to specific fungal symbionts, a wide range of tolerance to abiotic environmental conditions in the offspring of populations occurring in continental climate, and germination strategies closely linked to the ecological niche of the species. The existing studies do not clearly indicate whether tree adaptations are shaped by epigenetics or phenology and do not define the role of phenotypic plasticity in tree development. We have created a juxtaposition of literature that is useful in identifying the factors that play key roles in these processes. We compare scientific evidence that species distribution and survival are possible due to phenotypic plasticity and thermal memory with studies that testify that trees' phenology depends on phylogenesis, but this issue is still open. It is possible that studies in the near future will bring us closer to understanding the mechanisms through which trees adapt to stressful conditions, especially in the context of epigenetic memory in long-lived organisms, and allow us to minimize the harmful effects of climatic events by predicting tree species' responses or by developing solutions such as assisted migration to mitigate the consequences of these phenomena.
\end{abstract}

Keywords: global climate change; forest ecology; trees adaptation; phenotypic plasticity

\section{Introduction}

Recent changes in the global climate have a considerable impact on many aspects of the natural environment and various aspects of human economy [1,2]. In addition, there is a fierce social and scientific debate concerning the origin of the climate changes that are presently being observed [3]. The results of many scientific studies show that human activity has contributed to the increase in $\mathrm{CO}_{2}$ in the atmosphere; increased $\mathrm{CO}_{2}$ levels cause an increase in the frequency of extreme weather events [4], and such events were not seen as often before 2010 as they have been since then. For example, between May and July 2018, almost every day, approximately $22 \%$ of the populated and agricultural areas north of $30^{\circ}$ latitude experienced high temperature extremes at the same time [5]. Over a wide range of climate changes, the most severe are those related to changes in the temperature 
range. Forecasts for the coming decades predict that approximately a third of the permafrost will disappear after the global surface temperature rises by $2{ }^{\circ} \mathrm{C}[6]$. On the one hand, water levels are increasing with the shrinking of the area covered by ice $[7,8]$ and there are an increasing number of cases of rising flood risks in coastal areas due to sea level rise [9]; on the other hand, we are experiencing increasing levels of drought-endangered areas and drought [10]. These changes in environmental conditions are also a catalyst of shifts in the geographical ranges of many trees and shrubs [11,12]. Long-lived organisms are most at risk of changes that (i) could modulate their metabolism and cause species to adapt to new conditions or (ii) could have an impact severe enough to cause the death of the organism. The changes in the climate are believed to greatly affect the state of worldwide arboreal flora. We must take into account the fact that tree species differ in their ability to adjust to new conditions and in the rate at which they are able to do so. Overall, changing climate introduces considerable shifts in selective pressure in tree populations, and these shifts may result in different distributions of individual species in the future $[13,14]$.

We review and discuss various aspects of the modulation of tree physiology at the seed stage, at the germination stage and during further development stage, such as phenology, epigenetics and phenotypic plasticity, from the perspective of adaptation to rapidly changing climate. This work is an attempt to understand the pathway of changes that affect ecological connections between different species of trees and their rapidly changing environment. With this perspective, we attempt to predict how the current situation may evolve. This understanding may bring us closer to more adequately planning ways in which we can conquer the danger to biodiversity that arises from a changing climate.

\section{Forest Threats Related to Global Warming}

Due to increasing temperatures, the scale of the problem of global drought-induced stress and mortality of forest species is currently increasing at a rate unprecedented in recorded history $[15,16]$. During a 4-year extreme drought lasting from 2012 to 2015 in California, tree mortality increased from tens to hundreds of dead trees e.g., Abies magnifica (A. Murr), Abies concolor (Gord. \& Glend.), Lithocarpus densiflorus (Hook. \& Arn.) and Pseudotsuga menziesii (Mirb.) [17] per $\mathrm{km}^{2}$. It is therefore important to determine whether the mortality of trees in drought-affected areas will be concentrated in specific competitive and climatic conditions because this determination will enable forest managers to effectively identify areas that are more vulnerable to drought. Large-scale, consistent monitoring of forest ecosystems plays a key role in preparing for the impact of extreme events on the stability of forests [18].

To predict the traits of plants that are likely to die or to survive during drought under the influence of a future warmer climate, Darcy's law, which describes the relationship between the instantaneous discharge rate through a porous medium, the viscosity of the fluid and the decrease in pressure over a given distance, can be used. Through application of this core principle of vascular plant physiology, it has been established that it is likely that tall plants with isohydric stomatal regulation, low hydraulic conductance and high leaf area as trees' species from Fagaceae and Sapindaceae families will die because of drought stress in the future [19]. The rise in temperature is a cause of increasing vapor pressure deficits, and the resulting water stress will result in changes in the plants' structure. Old-growth forest mortality is likely to increase in a warming climate, while low-statured plants will probably survive, and forest ecosystems will be gradually replaced by communities of shorter grasses or shrubs [20].

\subsection{Direct Impact of Global Warming on Forests-Abiotic Factors}

\subsubsection{Responses at the Seed Level}

The role of different stages of thermal history, including previous generations and stages of flowering and seed development, still requires careful investigation [21-25]. The results of some studies suggest that there is an interaction between provenance and climate that has a significant impact on successful development and survival and that phylogenetic signals do not play an important 
role in this adaptation [26]. Thermal signals shape the successive steps of seed production, dormancy and germination; however, due to phenotypic plasticity, those processes also have thermal memory that contains their thermal experience from the past $[25,27]$. Microclimate may be the factor that most affects seed germination and early seedling establishment [13,28-31].

An important factor in the distribution of plant species is their germination behavior, one of the earliest phenotypes expressed by plants. This process frequently undergoes natural selection before other traits become observable because it is expressed early [30]. At this phase of life, plants are most susceptible to environmental stress. Researchers [32,33] have found that it is necessary to include seed size, lifespan and germination base temperature when analyzing the thermal limits of species distributions.

Seeds of phylogenetically related Caragana species that have germinated under different temperature and moisture conditions have shown differences in germination strategies that are tightly linked to the ecological niche of the species. This outcome indicates that the germination process is driven not by phylogenetic signals but by environmental causes [30]. Moreover, sycamore maple (Acer pseudoplatanus L.) seed lots collected along a north-south gradient spanning $21^{\circ}$ of latitude in Europe differed in maturity, and the level of maturity was influenced by the heat sum during seed development. Seeds from colder locations, for example, Scotland, germinated over a narrower temperature range and were more desiccation-sensitive than seeds from Italy and France, where the heat sum could be as much as two times higher [31].

Seeds of pendunculate oak (Quercus robur L.) from oceanic climates in West Poland required more humid and warmer conditions for epicotyl emergence, while in seeds from continental climates in East Poland, epicotyl emergence occurred both in cold-dry and warm-wet conditions. This observation shows that populations are adapted to their local environments [28]. Therefore, seed germination strategy is not a stable evolutionary trait within a family or genus [30]. Fremont cottonwood (Populus fremonti Wats.) trees from populations occurring in warmer, southern climates exhibited up to four times greater plasticity than populations adapted to cooler northern conditions. The value of phenotypic plasticity is correlated with the local climate. Trees experiencing hotter climates generally exhibited smaller shifts in an adaptive direction compared to trees transferred to cooler climates, which showed non-adaptive changes [29].

\subsubsection{Biochemical and Physiological Plant Responses}

Under conditions of poor water availability caused by dryness, plants experience water stress. In response, multiple signaling pathways and response mechanisms are activated to counteract water loss and allow the plant to adapt to the resulting dangers.

When the level of water in a plant decreases significantly, its cells begin to lose turgor, resulting in plasmolysis. On the macroscopic scale, this phenomenon manifests as shoots becoming flaccid and leaves wrinkling and folding. When only $20 \%$ of the original amount of water remains in the plant's cells (a state known as desiccation), the cell membrane begins to shatter and lose its selective properties. Phospholipids assemble in hexagonal structures instead of in a bilayer. Proteins begin to lose their native structures due to changes in the distribution of electrical charges caused by increased salt concentration [34-37].

Among the physiological changes that occur in plants during water stress, osmotic adaptation is worth noting. It depends on the production and accumulation of osmolytes such as proline, mannitol, glucose and fructose, which help maintain the water potential of the plant's tissues at a level that effectively counteracts the water loss. Accumulation of inorganic ions in vacuoles also helps overcome soil salinity, preventing water intake [34]. There is effective vacuolar sequesteration of $\mathrm{Na}+$ in Pongamia pinnata L. roots. These roots are thus a kind of filter, preventing the accumulation of excess $\mathrm{Na}+$ in the leaf [38].

Another type of response is increased production of particular phytohormones that affect metabolism in a way that counteracts water stress. For instance, abscisic acid (ABA) stimulates a number of physiological changes, including increased emergence of cilia on the epidermis, lower viability of 
generative organs, flower drop, stimulation of root growth and inhibition of shoot growth [39-42]. When these changes occur, water usage by above-ground organs is limited, and roots that are extended quickly have a greater likelihood of reaching more humid soil levels. Observations of this phenomenon are pointing to plasticity in root stress response [43]. On the other hand, research at Oak Ridge, USA has not confirmed that the tree root system clearly reacts to drought [44]. In trees, an additional strategy is leaf drop stimulated by ethylene $[45,46]$. The variant of this strategy called cladoptosis, which depends on dropping whole shoots instead of merely leaves, occurs in the species Quercus. This variant reduces the amount of metabolically active, water-consuming tissues and cuts off the main pathway of water loss through transpiration [47].

One of the most important defense strategies used by plants is limitation of transpiration. First, ion pumps are activated in the cells surrounding stomata. The osmotic effect results in a change in the cells' turgor due to water accumulation and in eventual closure of the stomata [48-50]. This change makes transpiration virtually impossible because the above-ground organs of land plants are covered by a protective wax cuticle. Another step in limiting water loss is increased production of the aforementioned wax [51]. It has been shown that leaf area and leaf production decline with increasing water stress. Leaf area and transpiration rates were lower in water stressed than in non-water stressed plants [52-54]. However, it turns out that leaf area alone could not determine the rate of transpiration, because in some cases small leaves transpire more than large leaves, due to differences in the size and density of stomata on the leaf surface [55]. In the case of baobab (Adansonia digitata L.), it was confirmed that the higher the temperatures at which trees live, the denser is the distribution of stomata on the leaf surface [56].

The main negative consequence of stomata closure is lockdown of gas exchange between the plant and its environment. Carbon dioxide, which is necessary for photosynthesis, cannot make its way into the leaf. This outcome leads to a significant decrease in the concentration of this compound in leaf cells within a short time. $\mathrm{CO}_{2}$ deficiency leads to effective competition by $\mathrm{O}_{2}$ for the active center of the Rubisco enzyme [57-59]. Rubisco is known for its tendency to recognize $\mathrm{O}_{2}$ instead of $\mathrm{CO}_{2}$ as a substrate for connection with ribulose 1,5-bisphosphate (RuBP), which begins the photorespiration pathway. The plant does not benefit energetically from this process and loses a significant amount of carbon, as $\mathrm{CO}_{2}$ is one of the byproducts. This outcome lowers the overall efficiency of photosynthesis. This tendency manifests mostly when the $\mathrm{CO}_{2}$ to $\mathrm{O}_{2}$ ratio in cells is low. High temperature of the reaction environment is also a stimulating factor. Metabolic pathways aimed at eliminating the harmful glyoxylate formed in this process require hydrogen peroxide, resulting in greater production of this molecule in peroxisomes $[60,61]$. Forest trees have $C 3$ metabolism, thus, competition between substrates at the Rubisco level, which is dependent on temperature, with the ratio of oxygenation and carboxylation increasing with increasing temperature [59]. In the case of Quercus pubescens Willd., photosynthesis may be temporarily affected by a heat-dependent reduction of Rubisco activation state. Therefore, $Q$. pubescens is an example of species which may be negatively affected by the heat waves, which occur currently and could occur in the near future [62].

In the context of the light phase of photosynthesis, carbon dioxide deficiency limits the regeneration of the oxidized form of nicotinamide adenine dinucleotide phosphate (NADP). Accumulation of the reduced form of this nucleotide results in blockage of the electron transport pathway in the thylakoid membrane. The persistent reduced state of the chain complexes results in disruption of the balance of chloroplasts' redox state. A side effect is oxygen reduction on photosystem I in the Mehler reaction $[61,63,64]$. This reaction is often incomplete, resulting in the formation of a superoxide anion radical and hydrogen peroxide $[59,64-66]$. To balance the redox potential of the cell, the NADPH reduction potential is transported through a system of molecular "shuttles" to the cytosol and then to mitochondria, where it is used to feed the respiratory chain [67-69]. Excessive reduction of protein chain complexes, in particular complex III, in a manner analogous to that occurring in chloroplasts results in the formation of superoxide anion radicals [70-72]. In this context, the plant's defensive action is to increase the expression of alternative oxidase (AOX) [73-76]. This enzyme acts as a "safety 
valve" to eliminate the accumulating reductive force and thus limit the production of reactive oxygen species (ROS) [77].

Heat leads to denaturation of the protein components of cell membranes because it accelerates the movement of lipids. In effect, it makes cell structures more sensitive, which leads to the disruption of physiological and cellular processes such as ion transport and photosynthesis [78-80]. Concurrently, heat increases the formation of ROS, as which superoxide radical $\left(\mathrm{O}_{2}^{-\bullet}\right)$, hydrogen peroxide $\left(\mathrm{H}_{2} \mathrm{O}_{2}\right)$ and hydroxyl radical (.OH), are classified (Figure 1). Notably, studies on tree species of Dipterocarpaceae family have shown that species which occur at uplands and riparian fringes with a higher frequency of disturbances, are suggested to have higher photosynthetic tolerance to elevated temperatures [81].

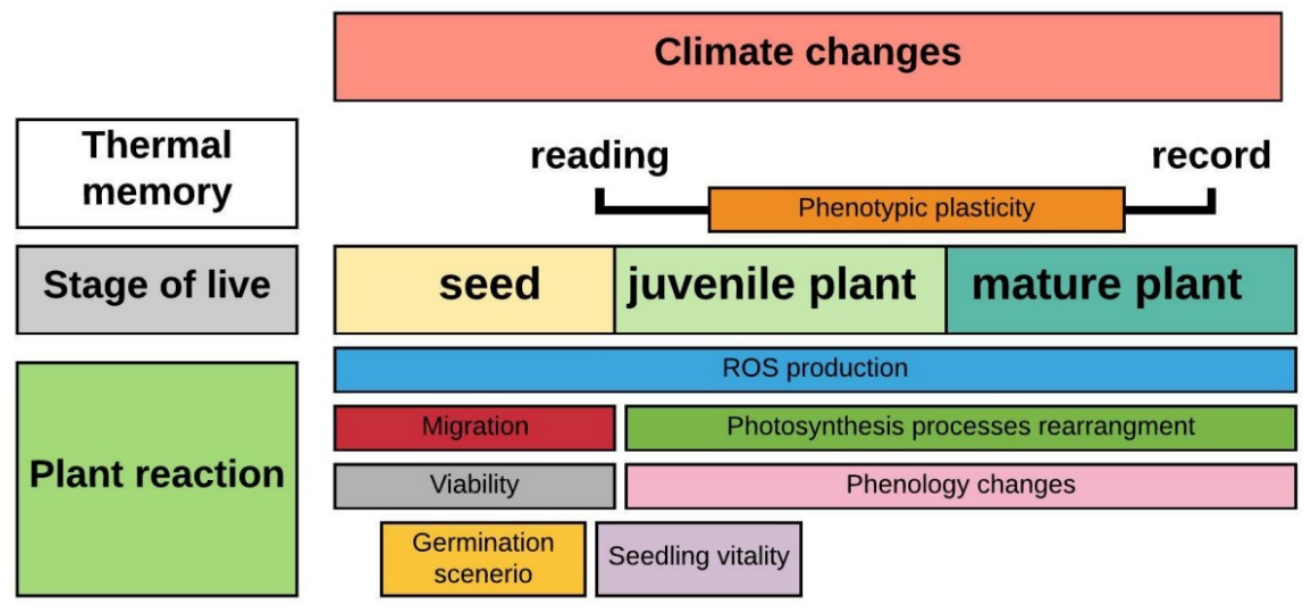

Figure 1. Rapid changes in climate conditions influence each of stage of a plant's life, from seed production by juvenile and mature plants. Thermal memory recorded due to phenotypic plasticity in mature organisms is passed on to the seed, in which the thermal memory is read. As a consequence of climate changes, reactive oxygen species ROS production may change at each of stage of life; important differences in the proper functioning of photosynthesis also occur. Acceleration or delay of developmental programs is observed as a change in the phenology of the species. Changes in the climate may interfere with the viability of seeds and may cause modifications in germination scenarios or seedling vitality. Seeds are plant organs that may, as a consequence of these events, migrate to establish new territory and change the range of populations and even species.

These molecules are characterized by extremely high reactivity. They easily react with cell-building macromolecules, mainly in the mitochondria, chloroplasts and peroxisomes $[59,82,83]$ disrupting their structure and function [84]. The loss of seed viability during storage at temperatures above $0{ }^{\circ} \mathrm{C}$ is closely linked to ROS production, and the antioxidant system is not always sufficient to protect them [85]. ROS induce oxidative damage to nucleic acids, lipids and proteins, thereby affecting organelles and their metabolic integrity [86-91]. These reactions include lipid peroxidation (LPO) (a process of oxidation of polyunsaturated fatty acids by $\mathrm{O}_{2}^{-\bullet}$ ) [92], oxidation of protein disulfide bonds and peroxidation of lipids and proteins by $\mathrm{H}_{2} \mathrm{O}_{2}[36,93,94]$. Excessive accumulation of reactive oxygen species causes irreversible damage of the cell and leads to cell death $[90,95]$. The presence of ROS stimulates the defense response in the form of increased activity of enzymes that catalyze the breakdown of harmful substances into less reactive forms. These include peroxidases, which catalyze the conversion of hydrogen peroxide to molecular oxygen and water, and superoxide dismutase (SOD), which catalyzes the decomposition of anion radicals to less harmful $\mathrm{H}_{2} \mathrm{O}_{2}$ [96,97]. A number of small molecular substances such as reduced glutathione, tocopherol and ascorbic acid also participate in these reactions. Tocopherol is anchored in the cell membrane, where it protects lipids from peroxidation. With the participation of appropriate peroxidases, ascorbic acid and glutathione are oxidized during the $\mathrm{H}_{2} \mathrm{O}_{2}$ decomposition reaction, thereby decreasing the overall quantity of these molecules in the cell $[98,99]$. 


\subsection{Indirect Impact of Global Warming on Forests-Biotic Threats}

Climate change is already influencing the geographic distribution of pathogens and insects that prey on tree species. The changes facilitate the expansion not only of exotic pests but also of native pests. In addition, climate change can affect tree resistance to pests, and this is an increasingly frequent phenomenon $[14,100]$. Temperature is a main factor affecting many of the insect life-history events on which population success depends [101]. Climate change contributes to shorter generation times of forest insect species. For example, an increase in temperature can facilitate survival of winter conditions by the mountain pine beetle (Dendroctonus ponderosae Hopkins) [102], which is the most serious insect pest of western North American pine forests, and its outbreak a few years ago caused the destruction of over 15 million hectares of pine forests. This event had a significant impact on forest health and the economy of the woodworking industry [103]. Moreover, drought is one of the most important climatic factors affecting host trees' susceptibility to forest insects because reduced water availability threatens the resilience and viability of trees [100]. The simultaneous occurrence of invasive insect outbreaks in forests and the weakening of trees' resistance to their attacks results in increased tree mortality. Drought is thought to be the main cause of infestation by several defoliators and bark beetle species, as well as pathogens $[9,104]$. For example, susceptibility to occupation of Norway spruce stands in Poland by pests is relatively high because this tree species possess a shallow root system; therefore, it experiences drought stress more rapidly than deep-rooted species, and at the same time, the production of resin, which is used to repair injuries, including insect bites, is reduced [105,106]. As a consequence, the number of bark beetles (Ips typographus L.) is changing rapidly, resulting in a serious problem of massive dying-off of Norway spruce stands in northeastern Poland and, at the international scale, infecting areas such as the Białowieża Forest [107]. Since 2012, spruce stands covering a total area of approximately 1.4 million $\mathrm{m}^{3}$ have died (www.bialystok.lasy.gov.pl). The development and reproduction of the bark beetle population are stimulated by factors such as high temperature and low precipitation. An increase in the number of bark beetles, a species with high reproductive potential that can produce two main generations and one or two sister generations in a year, usually leads to catastrophic effects and significant economic losses throughout the area occupied by Norway spruce [108]. Climate change may also be a reason for an increase in the harmful activity of species that previously did not have significant economic significance in a given area. The main factor limiting the occurrence of Nodiprion sertifer (Geoffr.) in northern Finland is the occurrence of days with a temperature lower than $-36^{\circ} \mathrm{C}$ in winter; below this temperature, high egg mortality is recorded. In the same research, the scenario that would be expected to occur following an increase of $3.6^{\circ} \mathrm{C}$ in the average winter temperature by 2050 was considered. Climate warming may lead to an increase in the frequency of gradation of tropical blue bees in areas where sporadic or non-occasional occurrence is presently found [109]. The impacts of climate change on forest insect and pathogen populations is an important research focus because management of the impact of invasive exotic and native pests becomes increasingly difficult [110]. Changes in the ranges of insects resulting from the impact of changed climate parameters may also result in their adaptation to new food plants. When species closely related to the original food plant are present in the new area of phytophage occurrence, it is possible that pests will broaden the spectrum of the host plants they feed on [111]. An increase in the average temperature over several decades has resulted in the expansion of the pine processionary (Thaumetopoea pityocampa Schiff.); to date, this expansion has been observed in the Sierra Nevada mountains of southeastern Spain, above the free parts of the mountains and extending into the areas of the mountains far beyond. The change in distribution was also accompanied by adaptation to a new host plant, a relict subspecies of the common pine, Pinus sylvestris var. nevadensis [112].

Fungi forest pathogens represent another important group of invasive organisms [113], and the major pathway for introduction of these pathogens is human-mediated transport [114]. An example of a common forest disease in Europe is oak powdery mildew [115], which is caused by a few species of Erysiphe. Epidemics of this pathogen have been observed in several years. According to the latest research, the increase in temperature related to greenhouse gas emissions has resulted in a marked 
increase in winter precipitation in northern Eurasia and eastern North America since 1920 [116]. The results of one study [117] showed that illness peaks occurred only after mild winters, although it was believed that climatic factors during the growing season have a greater impact on disease dynamics. The authors of this study also showed that there are evident interactions between powdery mildew infection and oak growth dynamics. It is possible that temperature conditions that occur in winter favor the perennation of powdery mildew fungi [118]. Moreover, cold winters limit overwintering of powdery mildew mycelia in leaves and buds [119] and cause limited survival of chasmothecia [120,121].

A loss of biodiversity can be indirectly related to climate, as it may be caused by shifts in the habitats of invasive species. In Western Europe, there are reports of potential invasion by several tree species from North America. These species include Quercus rubra L. and Robinia pseudoacacia L. The invasive potential of these species, favored by changing climate, is expected to jeopardize the biodiversity of the invaded regions. As of the writing of this document, the area of Europe harboring hospitable conditions for these species is thought to be halfway occupied [122].

\section{Novel Environmental Conditions as Changes Generator}

Tree species living in rapidly changing climate conditions are exposed to danger and must adapt to new climate conditions to survive. Trees respond to changes in the environment in numerous ways. Physiological modulation at the seed stage, germination strategy and further development are influenced by many different factors [13,14].

Research by [123] on Norway spruce (Picea abies L.) shows that the adaptive abilities of particular tree species can be surprisingly high. The authors discovered a form of adaptation that is passed to the offspring and is based on epigenetic memory. The length of day and temperature conditions under which parent plants were maintained influenced the growth of their progeny during the following year. This influence indicates that in some cases, trees are able to adapt surprisingly quickly to a changing environment (Table 1).

A warming climate results in earlier leaf unfolding in spring for many tree species, increasing the risk of exposure of juvenile leaves to frost damage. [126] examined 13 species of trees and shrubs in Switzerland and compared the measurement results obtained over a 60-year period. There was a noticeable trend of leaf unfolding occurring earlier in later years that correlated with the increase in global temperatures.

Lankau et al. [127] explored how climate change affects trees' production of mycorrhiza, with distinction between ectomycorrhiza and arbuscular mycorrhiza. Both types of symbiosis are observed to mitigate the sensitivity of trees to changing climate. Further research is needed to verify the deeper connections between changing climatic conditions and the relationships between trees and their symbiotes.

Another study [128] described the relationship of pinyon pine (Pinus edulis Engelm.) and its ectomycorrhizal fungal communities (EMFs). Pinyon pines with particular genotypes are observed to associate only with particular EMFs. Additionally, mycorrhizal fungi of different species provide different types of enhanced resistance for their tree counterparts. Both drought-resistant and drought-resilient species of plants showed signs of improved drought survival when associated with fungi of the genus Geospora. Affinity for specific fungal symbionts is part of a tree's phenotype and may serve as a form of adaptation.

Populations of trees of the same species may differ in phenotype. Fagus sylvatica (L.) in populations located in the core of the species' aerial range appeared to be the most susceptible to intense drought and suppressed growth. On the other hand, the highest durability was observed in populations located in the edges of their habitat close to the equator. This observation leads to the conclusion that future changes in temperature and overall climate might effectively compromise the range of this species, which is currently dominant in Europe [129]. 
Table 1. Diversifying the forms of adaptation of selected tree species to changing climatic conditions.

\begin{tabular}{|c|c|c|c|}
\hline Stage of Development & Species & Type of Adaptation & References \\
\hline Seed stage & $\begin{array}{l}\text { Quercus petraea (Matt.) } \\
\text { Liebl. } \\
\text { Quercus robur L. }\end{array}$ & $\begin{array}{l}\text { Increasing temperature improve } \\
\text { seed resistance to environmental } \\
\text { stress and increase germination } \\
\text { efficiency }\end{array}$ & [124] \\
\hline \multirow[t]{2}{*}{ Germination stage } & Caragana ssp. & $\begin{array}{l}\text { Germination strategies tightly } \\
\text { linked to the ecological niche of } \\
\text { the species }\end{array}$ & {$[30]$} \\
\hline & Quercus robur L. & $\begin{array}{l}\text { Offspring of the population } \\
\text { occurring in the continental } \\
\text { climate has a wide range of } \\
\text { tolerance to abiotic environmental } \\
\text { conditions }\end{array}$ & [28] \\
\hline \multirow[t]{4}{*}{$\begin{array}{l}\text { Further developmental } \\
\text { stages }\end{array}$} & Picea abies L. & $\begin{array}{l}\text { Epigenetic "memory": impact of } \\
\text { simulated length of day and } \\
\text { temperature, in which parent } \\
\text { plants were kept, on the growth of } \\
\text { their progenies }\end{array}$ & [123] \\
\hline & Populus fremonti Wats. & $\begin{array}{l}\text { Offspring of the populations } \\
\text { occurring in warmer conditions } \\
\text { shows four times greater plasticity, } \\
\text { unlike the populations that } \\
\text { adaptedto cooler conditions }\end{array}$ & [29] \\
\hline & Picea mariana Mill. & $\begin{array}{l}\text { The wide range of abiotic } \\
\text { conditions in which the species } \\
\text { occurs causes the formation of } \\
\text { populations that vary in terms of } \\
\text { specific adaptations to local } \\
\text { conditions }\end{array}$ & [125] \\
\hline & $\begin{array}{c}\text { Pseudotsuga menziesii } \\
\text { Mirb. }\end{array}$ & $\begin{array}{l}\text { Growth initiation on Douglas-fir } \\
\text { will track progressive changes in } \\
\text { favorable climatic conditions at } \\
\text { high elevations and latitudes }\end{array}$ & [12] \\
\hline
\end{tabular}

Trees are used as a popular countermeasure to reduce excessive heat in urban areas. This effect includes providing shade for trolley surfaces and cooling through transpiration. According to [130], specimens of Quercus ilex (L.) examined in four different urban sites were exposed to excessive water stress, which resulted in xylem cavitation, increased embolism and stomatal aperture. Under a continuous trend of summer heat waves, urban trees are at risk of dieback. On the other hand, there is some evidence that trees grow faster in urban areas. The rate of growth of urban trees appears to have increased since the 1960s, especially in cities located in the boreal climate zone [131]. It seems to be related to the urban heat island effect, which probably stimulates photosynthetic activity and extends the growing season [132]. However, in temperate climate, urban tree growth is not as significant. Trees probably suffer from substantial water stress, due to, e.g., impervious surfaces and compacted soils in urban areas, which may reduce root growth and in turn hamper a tree's water uptake [131].

\section{Climate Is an Important Selective Factor in Populations}

The plasticity of traits such as those discussed above is under the influence of evolutionary change and affects the long-term persistence of populations and their roles in ecosystems [133]. Many species are not able to migrate rapidly enough to keep up with the rapidly changing climate; therefore, adaptation must play a key role in their response [134]. In fragmented habitats, rapid climate 
change probably surpasses the capacity for adaptation in many plant populations, and their genetic composition may be dramatically altered as a result [135]. It is possible that the consequences will include unpredictable changes in the number of species within communities and a reduction in their ability to survive further environmental perturbations such as pest outbreaks, disease outbreaks and extreme climatic events [136].

In the near future, an increase in the frequency of extreme climatic events is predicted; thus, individuals would need to possess practically perfect plasticity to allow them to tolerate all fluctuations in climate conditions with no fitness losses [137]. The distributional changes and climate-related forest dieback that are currently taking place show that such universal plastic tolerance of the changing climate is not standard [138-141]. A plastic phenotype will enable plants to respond to climate changes during the lifetime of the individual (Figure 1); however, the capacity for a plastic response to an event is decreasing as more extreme events of greater extremes experienced and are lasting longer [136]. Therefore, the capacity of plants to respond to environmental changes by phenotypic plasticity has limits [134,142].

Tree species that are locally adapted at their limits of range could be beneficial for range expansion because, given that environmental conditions in new areas are similar to the current ones, colonizing genotypes are the fittest. If climate changes occur faster than trees' acquisition of the capacity to migrate, local adaptation can make their range expansion slower [13]. European beech (Fagus sylvatica L.) is an example of an expansive tree species, and ongoing changes in climate conditions could expand its potential range. Beech stand vitality is high, and its regeneration is well adapted to different site conditions at the limit of the species' distribution; thus, European beech will probably reach its northeastern limit in the future [143].

\section{The Impact of Phylogeny on Plant Phenology}

Despite the evidence that plant responses depend on abiotic conditions, it still has not been fully confirmed that seed germination, and consequently the distribution of species that evolved from the same ancestor, was formed under the influence of environmental conditions [13,28-30,144,145]. Some studies have found that tree phenology is determined by phylogenesis. When tree species from seven different biomes in the world were compared, species in the Arctic region were found to have a thermal upper limit lower than that of species in the rainforests. The maximum temperature difference for photosynthesis and respiration between species from Alaska and Peru was 9 degrees Celsius [146]. Among other findings, it was confirmed that species in North American forests have germination strategies similar to those of related species present in East Asia [147]. There is evidence that phylogenetic relationships are the factors that shape seed mass evolution. An increase in seed production, observed over the last decade in oaks in the temperate zone, increases seed dispersal [148]. Moreover, increasing temperature favors acorn mass increases (in case of Quercus petraea (Matt.) Liebl. and Quercus robur L., by about $0.15 \mathrm{~g}$ per degree [124], which can improve seed resistance to environmental stress and increase germination efficiency [149].

As a result of phylogenetic limitations, related species do not spread far from their optimal ecological niches, and they also exhibit similar seed germination strategies [32]. Numerous studies investigating the importance of phylogeny in determining responses to climate change have been published [150]; however, most of these studies address herbals [151,152] and plant life-history events such as flowering $[153,154]$ rather than trees or seed germination. A comparative analysis of phenological traits showed that the timing of life-history events covaries with phylogeny such that more closely related species tend to flower and leaf at similar times. Flowering time is a particularly conserved feature within tropical and temperate phylads [155]. It is possible that the phenology of flowering and seed development exhibits thermal memory. Flowering shows response to temperatures experienced comparably early in the maturation stage [156]. It has also been shown that seed weight depends on the duration of the flowering process [157]. Within natural populations, relatively rapid evolutionary changes can occur; however, the rate of temperature increase, which determines 
development, can be too rapid for populations to evolve in the absence of gene flow from populations of Betula with earlier dates of budburst [158]. Observations of the effects of temperature during ripening on the future features of the germination process suggest that plants' phenological thermal memory allows seeds to adapt their germination phenology to climate change. This phenomenon can help predict climate change [25].

Most published results indicate a positive effect of temperature increase on the seed germination process [159], but an experiment on 17 tree species in elevated temperature and $\mathrm{CO}_{2}$ concentration [160] showed that long-term exposure of the seeds to high temperature is probably the main cause of the decrease in seed germination. Moreover, high temperatures are the cause of thermo-dormant changes, which are variable depending on the genotype; thus, temperature-dependent hormones and enzymes may be inactivated [161]. After all, in many cases, unlike in the above-mentioned study, high temperature breaks seed dormancy and stimulates initiation of germination [162]. It cannot be excluded that global warming reduces the amount of chilling trees experience, and then more forcing may be required to start growth [163], wherein it causes changes in the timing of growth initiation to lag behind climate change [164]. Many tree species require chilling to start budburst [161] but some studies suggest that the observed trend toward earlier budburst will be reversed if winter temperatures increase substantially [165]. To determine if changes in phenology are likely to reflect climate change, ref [12] modeled related shifts in tree phenology. For this purpose, they analyzed the time of initiation of growth and diameter growth in coast Douglas fir (Pseudotsuga menziesii Mirb.), which is a species of ecological and economic importance in western North America. The created models showed that growth initiation in Douglas-fir will track progressive changes in favorable climatic conditions at high elevations and latitudes, but on the other hand, it will lag behind these shifts at lower latitudes and elevations [166]. Diameter-growth initiation does not appear to require some chilling, but it may cause shifts in the diameter-growth initiation behind climate change over a larger geographical area, compared to the height-growth initiation. It is therefore really important to analyze many growth-initiating events when studying the relationship between climate and tree growth phenology [167].

\section{Phenotypic Plasticity Allows Species to Survive under Novel Conditions}

Phenotypic plasticity is defined as the ability of an organism to change in response to stimuli or resources from the environment. The response may or may not be adaptive; if adaptive, it is called adaptive plasticity. It may involve a change in morphology or physiological state or both at any level of organization, wherein the phenotype consists of all of the characteristics of an organism other than its genes [168].

Natural populations with high levels of genetic variation are characterized by increased potential to adapt to abiotic and biotic environmental changes [168]. The populations adapt through natural selection or migrate to follow conditions to which they were initially adapted and, notably, these options are not mutually exclusive $[169,170]$. Plant species can adjust to changing environmental conditions through phenotypic plasticity. It is likely that by using discoveries in the field of molecular biology, which is constantly developing, we can understand the mechanisms that underlie phenotypic plasticity. There is evidence that such plasticity is hereditary and genetically controlled and that it contributes to evolution [171,172].

The role of epigenetics in the process of phenotypic plasticity remains unclear despite recent discoveries suggesting that it is of great importance $[173,174]$. Studies investigating the role of epigenetics in tree phenotypic plasticity concluded that epigenetic mechanisms in forest trees play a crucial role in plants' ability to withstand and adapt to stressful conditions. These mechanisms probably mediate phenotypic modifications that result in beneficial effects in response to the environment. Changes in DNA methylation may play a key role in phenotypic plasticity [175]. In 2010, a possible link between epigenetics and plasticity in response to drought stress in poplar was investigated [176], and it was possible to establish correlations between morphological and 
epigenetic variables. Correlations between DNA methylation levels and biomass productivity have been demonstrated in a collection of poplar genotypes grown outdoors under various moisture conditions [177]. Moreover, differences in transcript abundance levels under the influence of stress have been reported. The observed differences varied depending on the geographic provenance, leading to the assumption that DNA methylation may lead to phenotypic variation induced by stress factors through modulation of gene expression [178]. Variations in soil water availability preferentially drive changes in the DNA methylation levels of genes involved in phytohormone metabolism and signaling; these changes potentially promote phenotypic plasticity [179]. The high level of phenotypic plasticity found in stone pine trees is probably linked to epigenetic variation between individuals or populations [180]. This species is characterized by very low levels of genetic variation and high levels of plasticity for many traits. Using epigenetic markers, it was possible to discriminate between two populations that were indistinguishable using classical molecular markers [181].

Long life span is a trait of many species of forest trees, and processes such as growth, bud bursting time and resistance to frost may be subject to climatic conditions $[182,183]$. Norway spruce (Picea abies L.) is the tree species in which epigenetic memory has been most researched. It was shown that temperature-dependent epigenetic memory affecting the timing of bud burst and bud set in trees is generated by temperature changes during somatic embryogenesis [123]. Stem cuttings from poplar derived from populations located in areas with different amounts of phosphorus developed differently in the same habitat, despite their clonal origin. These differences in seedling growth strategy were associated with different levels of methylation of miRNAs as a function of primary environmental conditions, and it was a cause of habitat-dependent root modification under conditions of phosphate starvation [177].

\section{Future Perspective for Research and Practice Solution in Terms of Adaptation of Trees to a Rapidly Changing Climate}

\subsection{Preventing Harmful Climatic Events by Forecasting the Responses of Tree Species}

Range reduction could have serious consequences for nature protection and forest management [11]. Assisted migration cannot be used without determining the future climatic conditions. By employing databases on the current distributions of tree species and the latest climate scenarios, it is possible to predict the changes in the ranges of species that are likely to occur in the next decades [184].

Many models that address the current and predicted distribution of tree species have been developed. These models are based on different data sets and take into account different variants of future events [11]. Moreover, further properties were found that may be affected by species boundaries, and these may prove valuable in forecasting tree species' mortality. For example, a study conducted in the United States showed that hydraulic traits can influence species distributions and that knowledge of these traits may be valuable in forecasting drought-induced tree mortality [14]. A model developed as part of this study captured the high prevalence of aspen mortality in the western and southern limits of aspen distribution in this region. Modeling of climate space suitability for the Dipterocarp trees Sal (Shorea robusta Gaertn.) and Garjan (Dipterocarpus turbinatus Gaertn. F), which play an important role in the economies of many Asian countries, showed that annual precipitation is the main variable that explains the current and future distribution of these species [185]. The results of this study can be used to identify sensitive species habitats and in designing appropriate conservation activities.

Reference [11] identified areas in which potential climatic conditions will be optimal for the tree species most important in forest management in Europe and areas in which these species may be threatened in the future. This study showed that species that will increase their suitable habitat areas as a result of climate change are likely to be mostly late-successional species such as European silver fir (Abies alba Mill.) and European beech (Fagus sylvatica L.), while the distribution ranges of most pioneer species such as Scots pine (Pinus sylvestris L.) and silver birch (Betula pendula Roth) would decrease (Figure 2) [186]. 


\section{Future scenario}

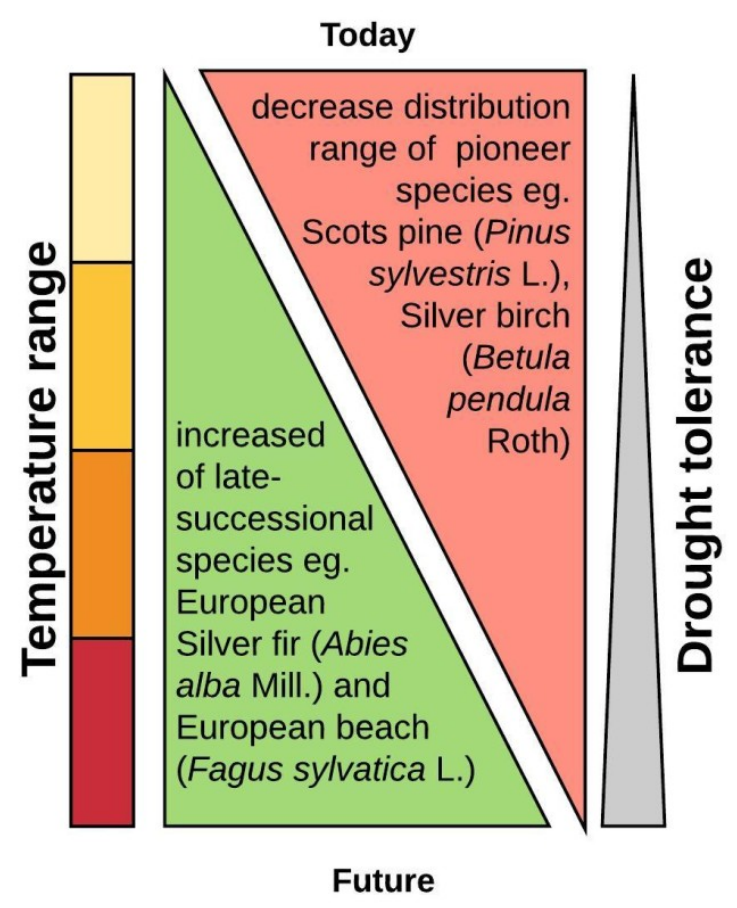

Figure 2. Diagram illustrating future scenario of tree species redistribution according to differences in the temperature range and drought tolerance of species grouped as pioneer and late-successional.

These findings show that the distribution of the studied species is mainly limited by water deficit during the growing season caused by more intense transpiration at higher temperatures [11]. In addition, Reference [27] indicated that models of future dispersal should consider how future climate conditions will impact seed number and mass, because these traits determine the dispersibility of individuals and populations and the health of their seedlings.

\subsection{When Adaptation Is not Fast Enough—Assisted Migration}

One solution that has been developed to mitigate the consequences of climate change is assisted migration [6]. Assisted migration relies on the purposeful movement of species to imitate or facilitate natural range expansion [187]. Assisted migration might be useful for locally adapted and long-lived populations or species, especially when their migration capacity is limited or when their habitats are threatened by fragmentation $[188,189]$. Using genotypes of Fremont cottonwood (Populus fremontii Wats.) from 16 populations from throughout the species' thermal range, it was shown that the beneficial plasticity of northern populations moved to hotter regions made it possible for these populations to experience relatively large amounts of warming before they reached a mortality threshold. In contrast, southern populations moved up in elevation and latitude showed non-adaptive, unfavorable plasticity responses [29]. Consequently, active management of the areas by methods such as assisted migration is truly needed. Climate change pushes the frost-line north; thus, the best solution, especially in areas in which winters are relatively warm, might be planting genotypes from lower elevations or latitudes adapted to long growing seasons. Long-lived trees can therefore benefit from plasticity to adapt to a rapidly changing environment $[29,190]$.

It will be necessary to match seed sources to the climates of the next decades to ensure the survival of forest tree species. Short-distance transfers could be used to buffer uncertainty about the scale of climate change in an area by improving the gene flow among populations by planting more diverse 
seed sources among and within forest stands [191,192]. Shifting climates may even render current species or populations non-adapted.

Understanding the process that can lead to production of refugia from contemporary climate change would be advantageous in preserving genetic diversity [193]. Because assisted migration certainly is not a solution consistent with our previous understanding of natural resource management or with previous views in conservation biology, it must be realized in such a way as to include valuation of species and population vulnerability to climate change, selections of options and management targets and long-term monitoring [186]. Such proceedings can become effective, inexpensive and practical options for addressing climate change. Currently, local assisted migration initiatives are underway in Canada and British Columbia [193].

\section{Conclusions}

Changes in climate conditions lead to global drought-induced stress and increase plant mortality. The impact of climate change is becoming much more noticeable from year to year. Nowadays, it is very important to monitor forest ecosystems, and each change should be described as a function of time and in relation to other factors, e.g., temperature, rainfall, etc. Collecting data on the changes in the phenology of species, changes in the related pathogens, insects and animals (number of species and time of settlement) is of real value in predicting the rates of change and their consequences. These changes may be manifested on a small scale as fragmentation and redistribution of populations, changes in range, and the development of adaptation; when the changes are too rapid or their impact is too great, they may be reflected in the death of organisms/populations, leaving ecological niches empty (Figure 3).

For proper interpretation of these changes, we should use a systems biology approach. Creation of a database that would compile observations from different levels of organism systematic versus changes in their ecological behavior and physiology may bring us closer to a comprehensive interpretation of the changes that occur due to rapidly changing climatic conditions.

Rapid climate change causes modifications in the physiology of trees at various levels ranging from molecular and biochemical changes to plant structural changes. Drought alone or drought followed by flood results changes in osmotic adaptation and in the accumulation of proline, mannitol, glucose and fructose, substances that play a key role in maintaining the water potential of plant tissues. Furthermore, drought leads to changes in the functioning of the photosynthetic apparatus that are reflected as stomata closure, carbon dioxide deficiency and limiting of transpiration. On the other hand, heat stress causes the denaturation of proteins in cell membranes and increases ROS production (Figure 3).

In spite of research results, which are not conclusive, it is possible that phenotypic plasticity has an important role in plants' adaptation to environmental changes. This finding places the issue of proper seed reserve conservation in gene banks in a new light. Reserves with the highest genetic diversity and from populations developed in different locations (with differences in adaptation to microclimate conditions) have the best opportunity to survive under new climate conditions and during changes in ecosystems that we cannot predict today. Epigenetic studies conducted in the next few years may bring us closer to understanding the mechanisms through which trees adapt to stressful conditions, especially in the context of epigenetic memory in long-lived organisms. The question "how does epigenetic memory develop according to the thermal history of the plant?" is still open. 


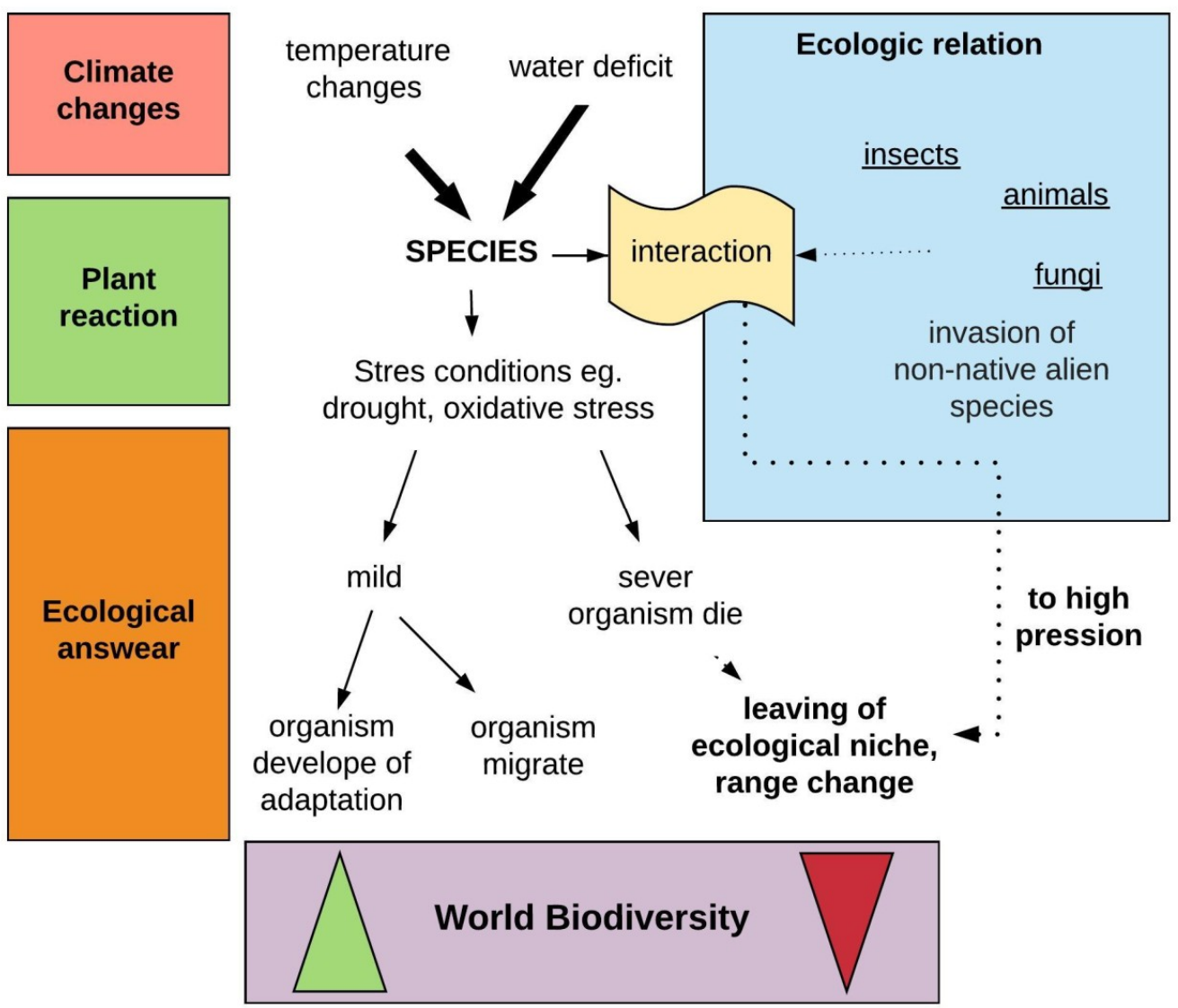

Figure 3. The relationship of climate change, plants' reactions and ecological behavior to world biodiversity. Rapid changes in climate (e.g., temperature and water status) influence species, and plant physiology changes in response to stress conditions. If stress conditions are mild, the organism may develop adaptation and protect the range of the population (increase in biodiversity), or migrate (no changes in biodiversity but changes in the distribution of species); severe stress may lead to death of the organisms and, in perspective, to an ecological decrease in world biodiversity. In ecosystems, plant species interact with other organisms such as fungi, animals, insects and invasive nonnative alien species. This interaction may aggravate stress, and when the pressure becomes too high, plant species may leave their niches, changing the range of species, and a decrease in world biodiversity would be observed.

Many scenarios and models based on different data sets and aspects have been constructed. We are still far from understanding how rapidly climate changes switch over plants from different biomes due to different strategies of plant population for microevolution, epigenetic memory and thermal history. Drought tolerance and adaptation during each stage of plant development are still considered to be main trait for developing future scenarios for forestry in the northern hemisphere. According to findings based on the drought tolerance of various species, mature late-successional species such as European silver fir (Abies alba Mill.) and European beech (Fagus sylvatica L.), will increase their range, in contrast to mostly pioneer species such as Scots pine (Pinus sylvestris L.) and silver birch (Betula pendula Roth), whose distribution may decrease (Figure 2).

Author Contributions: Conceptualization J.K.-O. and E.R.; Investigation, E.R.; Writing-Original Draft Preparation, J.K.-O. and J.K.; Writing-Review and Editing, E.R. and A.M.S.; Visualization, E.R. and A.M.S.; Supervision, E.R.; Funding Acquisition, E.R. All authors have read and agreed to the published version of the manuscript.

Funding: This research was supported by the National Centre of Sciences (grant number 2018/31/B/NZ9/01548). Additional funding was provided by the Institute of Dendrology, Polish Academy of Sciences.

Conflicts of Interest: The authors declare that they have no conflict of interests. 


\section{References}

1. Ebele, N.E.; Emodi, N.V. Climate Change and Its Impact in Nigerian Economy. J. Sci. Res. Rep. 2016, 10, 1-13. [CrossRef] [PubMed]

2. Costinot, A.; Donaldson, D.; Smith, C. Evolving Comparative Advantage and the Impact of Climate Change in Agricultural Markets: Evidence from 1.7 Million Fields around the World. J. Political Econ. 2016, 124, 205-248. [CrossRef]

3. Stolpe, M.B.; Medhaug, I.; Knutti, R. Contribution of Atlantic and Pacific Multidecadal Variability to Twentieth-Century Temperature Changes. J. Clim. 2017, 30, 6279-6295. [CrossRef]

4. Anderson-Frey, A.K. Statistical Examination of Tornado Report and Warning Near-Storm Environments; The Pennsylvania State University: University Park, PA, USA, 2017; ISBN 9780355329568.

5. Vogel, M.M.; Zscheischler, J.; Wartenburger, R.; Dee, D.; Seneviratne, S.I. Concurrent 2018 Hot Extremes Across Northern Hemisphere Due to Human-Induced Climate Change. Earth's Future 2019, 7, 692-703. [CrossRef]

6. Wang, T.; O’Neill, G.A.; Aitken, S.N. Integrating environmental and genetic effects to predict responses of tree populations to climate. Ecol. Appl. 2010, 20, 153-163. [CrossRef]

7. Jakobson, L.; Vihma, T.P.; Jakobson, E. How does the shrinking sea ice influence changing wind speed over the Arctic Ocean? Presented at the AGU Fall Meeting, San Francisco, CA, USA, 12-16 December 2016.

8. Chambers, A. The Arctic's Shrinking Sea Ice Gives Way to Increasingly Navigable Shipping Corridors: GIS Based Analysis by Satellite Imagery and Radar Observation; Western Washington University: Washington, DC, USA, 2017.

9. Wdowinski, S.; Bray, R.; Kirtman, B.P.; Wu, Z. Increasing flooding hazard in coastal communities due to rising sea level: Case study of Miami Beach, Florida. Ocean. Coast. Manag. 2016, 126, 1-8. [CrossRef]

10. Young, D.J.; Stevens, J.T.; Earles, J.M.; Moore, J.; Ellis, A.; Jirka, A.L.; Latimer, A.M. Long-term climate and competition explain forest mortality patterns under extreme drought. Ecol. Lett. 2017, 20, 78-86. [CrossRef]

11. Dyderski, M.K.; Jagodziński, A.M. Drivers of invasive tree and shrub natural regeneration in temperate forests. Boil. Invasions 2018, 20, 2363-2379. [CrossRef]

12. Bigler, C.; Bugmann, H. Climate-induced shifts in leaf unfolding and frost risk of European trees and shrubs. Sci. Rep. 2018, 8, 9865. [CrossRef]

13. Solarik, K.A.; Messier, C.; Ouimet, R.; Bergeron, Y.; Gravel, D. Local adaptation of trees at the range margins impacts range shifts in the face of climate change. Glob. Ecol. Biogeogr. 2018, 27, 1507-1519. [CrossRef]

14. Anderegg, W.R.L.; Flint, A.; Huang, C.-Y.; Flint, L.; Berry, J.A.; Davis, F.W.; Sperry, J.S.; Field, C.B. Tree mortality predicted from drought-induced vascular damage. Nat. Geosci. 2015, 8, 367-371. [CrossRef]

15. Berg, N.; Hall, A. Increased Interannual Precipitation Extremes over California under Climate Change. J. Clim. 2015, 28, 6324-6334. [CrossRef]

16. Williams, A.P.; Seager, R.; Abatzoglou, J.T.; Cook, B.I.; Smerdon, J.E.; Cook, E.R.; Williams, P. Contribution of anthropogenic warming to California drought during 2012-2014. Geophys. Res. Lett. 2015, 42, 6819-6828. [CrossRef]

17. Eyre, F.H. Forest Cover Types of the United States and Canada; SAF: Washington, DC, USA, 1980; ISBN 978-0686306979.

18. De Andrés, E.G. Interactions between Climate and Nutrient Cycles on Forest Response to Global Change: The Role of Mixed Forests. Forests 2019, 10, 609. [CrossRef]

19. McDowell, N.G.; Allen, C.D. Darcy's law predicts widespread forest mortality under climate warming. Nat. Clim. Chang. 2015, 5, 669-672. [CrossRef]

20. Williams, A.; Allen, C.D.; Macalady, A.K.; Griffin, D.; Woodhouse, C.A.; Meko, D.M.; Swetnam, T.W.; Rauscher, S.A.; Seager, R.; Grissino-Mayer, H.D.; et al. Temperature as a potent driver of regional forest drought stress and tree mortality. Nat. Clim. Change. 2013, 3, 292-297. [CrossRef]

21. Fernández-Martínez, M.; Vicca, S.; Janssens, I.A.; Espelta, J.M.; Peñuelas, J. The North Atlantic Oscillation synchronises fruit production in western European forests. Ecography 2017, 40, 864-874. [CrossRef]

22. Koenig, W.D.; Knops, J.M.H.; Pesendorfer, M.B.; Zaya, D.N.; Ashley, M.V. Drivers of synchrony of acorn production in the valley oak (Quercus lobata) at two spatial scales. Ecology 2017, 98, 3056-3062. [CrossRef]

23. Vacchiano, G.; Ascoli, D.; Berzaghi, F.; Lucas-Borja, M.E.; Caignard, T.; Collalti, A.; Mairota, P.; Palaghianu, C.; Reyer, C.P.; Sanders, T.G.; et al. Reproducing reproduction: How to simulate mast seeding in forest models. Ecol. Model. 2018, 376, 40-53. [CrossRef] 
24. Bogdziewicz, M.; Szymkowiak, J.; Fernández-Martínez, M.; Peñuelas, J.; Espelta, J.M. The effects of local climate on the correlation between weather and seed production differ in two species with contrasting masting habit. Agric. For. Meteorol. 2019, 268, 109-115. [CrossRef]

25. Fernández-Pascual, E.; Mattana, E.; Pritchard, H.W. Seeds of future past: Climate change and the thermal memory of plant reproductive traits. Biol. Rev. Camb. Philos. Soc. 2019, 94, 439-456. [CrossRef] [PubMed]

26. Desnoues, E.; de Carvalho, J.F.; Zohner, C.M.; Crowther, T.W. The relative roles of local climate adaptation and phylogeny in determining leaf-out timing of temperate tree species. For. Ecosytems 2017, 4, 2-7. [CrossRef]

27. Jastrzębowski, S.; Ukalska, J. Dynamics of epicotyl emergence of Quercus robur from different climatic regions is strongly driven by post-germination temperature and humidity conditions. Dendrobiology 2019, 81, 73-85. [CrossRef]

28. Cooper, H.F.; Grady, K.C.; Cowan, J.A.; Best, R.J.; Allan, G.J.; Whitham, T.G. Genotypic variation in phenological plasticity: Reciprocal common gardens reveal adaptive responses to warmer springs but not to fall frost. Glob. Chang. Biol. 2019, 25, 187-200. [CrossRef] [PubMed]

29. Fang, X.-W.; Zhang, J.-J.; Xu, D.-H.; Pang, J.; Gao, T.-P.; Zhang, C.-H.; Li, F.-M.; Turner, N.C. Seed germination of Caragana species from different regions is strongly driven by environmental cues and not phylogenetic signals. Sci. Rep. 2017, 7, 11248. [CrossRef] [PubMed]

30. Daws, M.I.; Cleland, H.; Chmielarz, P.; Gorian, F.; Leprince, O.; Mullins, C.E.; Thanos, C.A.; Vandvik, V.; Pritchard, H.W. Variable desiccation tolerance in Acer pseudoplatanus seeds in relation to developmental conditions: A case of phenotypic recalcitrance? Funct. Plant. Boil. 2006, 33, 59-66. [CrossRef]

31. Moles, A.T.; Ackerly, D.D.; Webb, C.O.; Tweddle, J.C.; Dickie, J.B.; Pitman, A.J.; Westoby, M. Factors that shape seed mass evolution. Proc. Natl. Acad. Sci. USA 2005, 102, 10540-10544. [CrossRef]

32. Arène, F.; Affre, L.; Doxa, A.; Saatkamp, A. Temperature but not moisture response of germination shows phylogenetic constraints while both interact with seed mass and lifespan. Seed Sci. Res. 2017, 27, 110-120. [CrossRef]

33. Karley, A.J.; Leigh, R.A.; Sanders, D. Where do all the ions go? The cellular basis of differential ion accumulation in leaf cells. Trends Plant. Sci. 2000, 5, 465-470. [CrossRef]

34. Hayat, S.; Hayat, Q.; Alyemeni, M.N.; Wani, A.S.; Pichtel, J.; Ahmad, A. Role of proline under changing environments: A review. Plant Signal Behav. 2012, 7, 1456-1466. [CrossRef]

35. Anjum, N.A.; Sofo, A.; Scopa, A.; Roychoudhury, A.; Gill, S.S.; Iqbal, M.; Lukatkin, A.S.; Pereira, E.; Duarte, A.C.; Ahmad, I. Lipids and proteins-major targets of oxidative modifications in abiotic stressed plants. Environ. Sci. Pollut. Res Int. 2015, 22, 4099-4121. [CrossRef] [PubMed]

36. Sharma, A.; Shahzad, B.; Kumar, V.; Kohli, S.K.; Sidhu, G.P.S.; Bali, A.S.; Handa, N.; Kapoor, D.; Bhardwaj, R.; Zheng, B. Phytohormones Regulate Accumulation of Osmolytes Under Abiotic Stress. Biomolecules 2019, 9 , 285. [CrossRef]

37. Marriboina, S.; Attipalli, R.R. Hydrophobic cell-wall barriers and vacuolar sequestration of $\mathrm{Na}+$ ions are among the key mechanisms conferring high salinity tolerance in a biofuel tree species, Pongamia pinnata $\mathrm{L}$. pierre. Environ. Exp. Bot. 2020, 171, 103949. [CrossRef]

38. Reddy, A.R.; Chaitanya, K.V.; Vivekanandan, M. Drought-induced responses of photosynthesis and antioxidant metabolism in higher plants. J. Plant Physiol. 2004, 161, 1189-1202. [CrossRef] [PubMed]

39. Xiong, L.; Wang, R.-G.; Mao, G.; Koczan, J.M. Identification of Drought Tolerance Determinants by Genetic Analysis of Root Response to Drought Stress and Abscisic Acid1. Plant Physiol. 2006, 142, 1065-1074. [CrossRef] [PubMed]

40. Zhang, J.; Jia, W.; Yang, J.; Ismail, A.M. Role of ABA in integrating plant responses to drought and salt stresses. Field Crop. Res. 2006, 97, 111-119. [CrossRef]

41. Sah, S.K.; Reddy, K.R.; Li, J. Abscisic Acid and Abiotic Stress Tolerance in Crop Plants. Front. Plant Sci. 2016, 7, 63. [CrossRef] [PubMed]

42. Nirala, D.; Pant, N.; Rawat, M. Response of tree roots to drought condition: A review. Int. J. Chem. 2019, 7, 824-826. [CrossRef]

43. Joslin, J.D.; Wolfe, M.H.; Hanson, P.J. Effects of altered water regimes on forest root systems. New Phytol. 2000, 147, 117-129. [CrossRef]

44. Iqbal, N.; Khan, N.A.; Ferrante, A.; Trivellini, A.; Francini, A.; Khan, M.I.R. Ethylene Role in Plant Growth, Development and Senescence: Interaction with Other Phytohormones. Front. Plant Sci. 2017, 8, 6484. [CrossRef] 
45. Khan, N.A.; Khan, M.I.R.; Ferrante, A.; Poor, P. Editorial: Ethylene: A Key Regulatory Molecule in Plants. Front. Plant Sci. 2017, 8, 1782. [CrossRef] [PubMed]

46. Rust, S.; Roloff, A. Reduced photosynthesis in old oak (Quercus robur): The impact of crown and hydraulic architecture. Tree Physiol. 2002, 22, 597-601. [CrossRef] [PubMed]

47. Niinemets, Ü. Controls on the emission of plant volatiles through stomata: A sensitivity analysis. J. Geophys. Res. Space Phys. 2003, 108. [CrossRef]

48. Tombesi, S.; Nardini, A.; Frioni, T.; Soccolini, M.; Zadra, C.; Farinelli, D.; Poni, S.; Palliotti, A. Stomatal closure is induced by hydraulic signals and maintained by ABA in drought-stressed grapevine. Sci. Rep. 2015, 5, 12449. [CrossRef]

49. Agurla, S.; Gahir, S.; Munemasa, S.; Murata, Y.; Raghavendra, A.S. Mechanism of Stomatal Closure in Plants Exposed to Drought and Cold Stress. Kidney Dev. Dis. 2018, 215-232. [CrossRef]

50. Leuschner, C.; Wedde, P.; Lübbe, T. The relation between pressure-volume curve traits and stomatal regulation of water potential in five temperate broadleaf tree species. Ann. For. Sci. 2019, 76, 60. [CrossRef]

51. Le Provost, G.; Domergue, F.; Lalanne, C.; Campos, P.R.; Grosbois, A.; Bert, D.; Meredieu, C.; Danjon, F.; Plomion, C.; Gion, J.M. Soil water stress affects both cuticular wax content and cuticle-related gene expression in young saplings of maritime pine (Pinus pinaster Ait). BMC Plant Biol. 2013, 13, 95. [CrossRef]

52. Griñán, I.; Rodríguez, P.; Nouri, H.; Wang, R.; Huang, G.; Morales, D.; Corell, M.; Pérez-López, D.; Centeno, A.; Martin-Palomo, M.; et al. Leaf mechanisms involved in the response of Cydonia oblonga trees to water stress and recovery. Agric. Water Manag. 2019, 221, 66-72. [CrossRef]

53. Abdulrahman, A.A.; Oladele, F.A. Leaf size and transpiration rates in Agave americana and Aloe vera. Phytol. Balcan. 2017, 23, 95-100. [CrossRef]

54. Lazaridou, M.; Koutroubas, S.D. Drought effect on water use efficiency of berseem clover at various growth stages. In New Directions for a Diverse Planet: Proceedings of the 4th International Crop Science Congress Brisbane; Australian Society of Agronomy Inc.: Melbourne, Australia, 2004; Volume 26, ISBN 192084222.

55. Sanchez, A.C.; Haq, N.; Assogbadjo, A.E. Variation in baobab (Adansonia digitata L.) leaf morphology and its relation to drought tolerance. Genet. Resour Crop Evol. 2010, 57, 17-25. [CrossRef]

56. Flexas, J.; Medrano, H. Drought-inhibition of Photosynthesis in C3 Plants: Stomatal and Non-stomatal Limitations Revisited. Ann. Bot. 2002, 89, 183-189. [CrossRef]

57. Van Lun, M.; Hub, J.S.; Van Der Spoel, D.; Andersson, I. $\mathrm{CO}_{2}$ and $\mathrm{O}_{2}$ Distribution in Rubisco Suggests the Small Subunit Functions as a $\mathrm{CO}_{2}$ Reservoir. J. Am. Chem. Soc. 2014, 136, 3165-3171. [CrossRef]

58. Rennenberg, H.; Loreto, F.; Polle, A.; Brilli, F.; Fares, S.; Beniwal, R.S.; Gessler, A. Physiological Responses of Forest Trees to Heat and Drought. Plant Boil. 2006, 8, 556-571. [CrossRef] [PubMed]

59. Gill, S.S.; Tuteja, N. Reactive oxygen species and antioxidant machinery in abiotic stress tolerance in crop plants. Plant Physiol. Biochem. 2010, 48, 909-930. [CrossRef] [PubMed]

60. Tikkanen, M.; Aro, E.-M. Thylakoid protein phosphorylation in dynamic regulation of photosystem II in higher plants. Bioenergetics 2012, 1817, 232-238. [CrossRef] [PubMed]

61. Haldimann, P.; Feller, U. Inhibition of photosynthesis by high temperature in oak (Quercus pubescens L.) leaves grown under natural conditions closely correlates with a reversible heat-dependent reduction of the activation state of ribulose-1,5-bisphosphate carboxylase/oxygenase. Plant Cell Environ. 2004, 27, 1169-1183. [CrossRef]

62. Johnson, M.P. Photosynthesis. Essays Biochem. 2016, 31, 255-273. [CrossRef]

63. Foyer, C.H. Reactive oxygen species, oxidative signaling and the regulation of photosynthesis. Environ. Exp. Bot. 2018, 154, 134-142. [CrossRef]

64. Hideg, Éva A comparative study of fluorescent singlet oxygen probes in plant leaves. Open Life Sci. 2008, 3, 273-284. [CrossRef]

65. Dietz, K.-J.; Turkan, I.; Krieger-Liszkay, A. Redox- and Reactive Oxygen Species-Dependent Signaling into and out of the Photosynthesizing Chloroplast. Plant Physiol. 2016, 171, 1541-1550. [CrossRef]

66. Sweetlove, L.J.; Lytovchenko, A.; Morgan, M.; Nunes-Nesi, A.; Taylor, N.L.; Baxter, C.J.; Eickmeier, I.; Fernie, A.R. Mitochondrial uncoupling protein is required for efficient photosynthesis. Proc. Natl. Acad. Sci. USA 2006, 103, 19587-19592. [CrossRef] [PubMed]

67. Noctor, G.; De Paepe, R.; Foyer, C.H. Mitochondrial redox biology and homeostasis in plants. Trends Plant Sci. 2007, 12, 125-134. [CrossRef] [PubMed] 
68. Schwarzländer, M.; Finkemeier, I. Mitochondrial energy and redox signaling in plants. Antioxid. Redox Signal. 2013, 18, 2122-2144. [CrossRef] [PubMed]

69. Han, D.; Williams, E.; Cadenas, E. Mitochondrial respiratory chain-dependent generation of superoxide anion and its release into the intermembrane space. Biochem. J. 2001, 353, 411. [CrossRef] [PubMed]

70. Sharma, P.; Jha, A.B.; Dubey, R.S.; Pessarakli, M. Reactive Oxygen Species, Oxidative Damage, and Antioxidative Defense Mechanism in Plants under Stressful Conditions. J. Bot. 2012, 2012, 1-26. [CrossRef]

71. Pospíšil, P. Production of Reactive Oxygen Species by Photosystem II as a Response to Light and Temperature Stress. Front. Plant Sci. 2016, 7, 1950. [CrossRef]

72. Mittler, R.; Vanderauwera, S.; Suzuki, N.; Miller, G.; Tognetti, V.B.; Vandepoele, K.; Gollery, M.; Shulaev, V.; Van Breusegem, F. ROS signaling: The new wave? Trends Plant Sci. 2011, 16, 300-309. [CrossRef] [PubMed]

73. Feng, H.; Sun, K.; Li, M.; Li, H.; Li, X.; Li, Y.; Wang, Y. The expression, function and regulation of mitochondrial alternative oxidase under biotic stresses. Mol. Plant Pathol. 2010, 11, 429-440. [CrossRef]

74. Vanlerberghe, G.C. Alternative Oxidase: A Mitochondrial Respiratory Pathway to Maintain Metabolic and Signaling Homeostasis during Abiotic and Biotic Stress in Plants. Int. J. Mol. Sci. 2013, 14, 6805-6847. [CrossRef]

75. Saha, B.; Borovskii, G.; Panda, S.K. Alternative oxidase and plant stress tolerance. Plant Signal. Behav. 2016, 11, e1256530. [CrossRef]

76. Brosché, M.; Overmyer, K.; Wrzaczek, M.; Kangasjärvi, J.; Kangasjärvi, S. Stress signaling III: Reactive oxygen species (ROS). In Abiotic Stress Adaptation in Plants; Pareek, A., Sopory, S., Bohnert, H., Eds.; Springer: Dordrecht, The Netherlands, 2009; pp. 91-102. ISBN 978-90-481-3112-9.

77. Źróbek-Sokolnik, A. Temperature stress and responses of plants. In Environmental Adaptations and Stress Tolerance of Plants in the Era of Climate Change; Ahmad, P., Prasad, M.N.V., Eds.; Springer: New York, NY, USA, 2012; pp. 113-134. ISBN 978-1-4614-0814-7.

78. Ruelland, E.; Zachowski, A. How plants sense temperature. Environ. Exp. Bot. 2010, 69, 225-232. [CrossRef]

79. Wahid, A.; Gelani, S.; Ashraf, M.; Foolad, M. Heat tolerance in plants: An overview. Environ. Exp. Bot. 2007, 61, 199-223. [CrossRef]

80. Kitao, M.; Lei, T.T.; Koike, T.; Tobita, H.; Maruyama, Y.; Matsumoto, Y.; Ang, L.-H. Temperature response and photoinhibition investigated by chlorophyll fluorescence measurements for four distinct species of dipterocarp trees. Physiol. Plant 2000, 109, 284-290. [CrossRef]

81. Mittler, R. Oxidative stress, antioxidants and stress tolerance. Trends Plant Sci. 2002, 7, 405-410. [CrossRef]

82. Suzuki, N.; Miller, G.; Salazar, C.; Mondal, H.A.; Shulaev, E.; Cortes, D.F.; Shuman, J.L.; Luo, X.; Shah, J.; Schlauch, K.; et al. Temporal-spatial interaction between reactive oxygen species and abscisic acid regulates rapid systemic acclimation in plants. Plant Cell 2013, 25, 3553-3569. [CrossRef]

83. Pukacka, S.; Malec, M.; Ratajczak, E. ROS production and antioxidative system activity in embryonic axes of Quercus robur seeds under different desiccation rate conditions. Acta Physiol. Plant. 2011, 33, 2219-2227. [CrossRef]

84. Pukacka, S.; Ratajczak, E. Production and scavenging of reactive oxygen species in Fagus sylvatica seeds during storage at varied temperature and humidity. J. Plant Physiol. 2005, 162, 873-885. [CrossRef]

85. Choudhury, S.; Panda, P.; Sahoo, L.; Panda, S.K. Reactive oxygen species signaling in plants under abiotic stress. Plant Signal. Behav. 2013, 8, e23681. [CrossRef]

86. Suzuki, N.; Koussevitzky, S.; Mittler, R.; Miller, G. ROS and redox signalling in the response of plants to abiotic stress. Plant Cell Environ. 2012, 35, 259-270. [CrossRef]

87. Kalemba, E.M.; Suszka, J.; Ratajczak, E. The role of oxidative stress in determining the level of viability of black poplar (Populus nigra) seeds stored at different temperatures. Funct. Plant. Boil. 2015, 42, 630-642. [CrossRef]

88. Ratajczak, E.; Małecka, A.; Bagniewska-Zadworna, A.; Kalemba, E.M. The production, localization and spreading of reactive oxygen species contributes to the low vitality of long-term stored common beech (Fagus sylvatica L.) seeds. J. Plant Physiol. 2015, 174, 147-156. [CrossRef] [PubMed]

89. Ratajczak, E.; Staszak, A.M.; Wojciechowska, N.; Bagniewska-Zadworna, A.; Dietz, K.J. Regulation of thiol metabolism as a factor that influences the development and storage capacity of beech seeds. J. Plant Physiol. 2019, 239, 61-70. [CrossRef] [PubMed]

90. Suzuki, N.; Mittler, R. Reactive oxygen species and temperature stresses: A delicate balance between signaling and destruction. Physiol. Plant 2006, 126, 45-51. [CrossRef] 
91. Repetto, M.; Semprine, J.; Boveris, A. Lipid Peroxidation: Chemical Mechanism, Biological Implications and Analytical Determination. Lipid Peroxidation 2012, 1, 3-30.

92. Leprince, O.; Buitink, J.; Hoekstra, F.A. Axes and cotyledons of recalcitrant seeds of Castanea sativa Mill. exhibit contrasting responses of respiration to drying in relation to desiccation sensitivity. J. Exp. Bot. 1999, 50, 1515-1524. [CrossRef]

93. Chmielowska-Bäk, J.; Izbiaå-Ska, K.; Deckert, J.; Izbiańska, K. Products of lipid, protein and RNA oxidation as signals and regulators of gene expression in plants. Front. Plant Sci. 2015, 6, 405. [CrossRef]

94. Bailly, C.; El-Maarouf-Bouteau, H.; Corbineau, F. From intracellular signaling networks to cell death: The dual role of reactive oxygen species in seed physiology. Comptes Rendus Boil. 2008, 331, 806-814. [CrossRef]

95. Berwal, M.K.; Ram, C.H. Superoxide Dismutase: A Stable Biochemical Marker for Abiotic Stress Tolerance in Higher Plants. In Superoxide Dismutase; Intech Open: London, UK, 2018. [CrossRef]

96. Caverzan, A.; Casassola, A.; Brammer, S.P. Reactive Oxygen Species and Antioxidant Enzymes Involved in Plant Tolerance to Stress. In Abiotic and Biotic Stress in Plants; Intech Open: London, UK, 2016; pp. 463-480. ISBN 978-953-51-2250-0.

97. Ratajczak, E.; Pukacka, S. Decrease in beech (Fagus sylvatica) seed viability caused by temperature and humidity conditions as related to membrane damage and lipid composition. Acta Physiol. Plant 2005, 27, 3-12. [CrossRef]

98. Nievola, C.C.; Carvalho, C.P.; Carvalho, V.; Rodrigues, E. Rapid responses of plants to temperature changes. Temperature 2017, 4, 371-405. [CrossRef]

99. Jactel, H.; Petit, J.; Desprez-Loustau, M.L.; Delzon, S.; Piou, D.; Battisti, A.; Koricheva, J. Drought effects on damage by forest insects and pathogens: A meta-analysis. Glob. Change Biol. 2012, 18, 267-276. [CrossRef]

100. Bentz, B.J.; Jönsson, A.M. Modeling Bark Beetle Responses to Climate Change. In Bark Beetles; Elsevier BV: Amsterdam, The Nederlands, 2015; pp. 533-553. ISBN 978-0-12-417156-5.

101. Bentz, B.J. Mountain pine beetle population sampling: Inferences from Lindgren pheromone traps and tree emergence cages. Can. J. For. Res. 2006, 36, 351-360. [CrossRef]

102. Keeling, C.I.; Yuen, M.M.S.; Liao, N.Y.; Docking, T.R.; Chan, S.K.; Taylor, G.A.; Palmquist, D.L.; Jackman, S.D.; Nguyen, A.; Li, M.; et al. Draft genome of the mountain pine beetle, Dendroctonus ponderosae Hopkins, a major forest pest. Genome Boil. 2013, 14, R27. [CrossRef]

103. Marini, L.; Ayres, M.P.; Battisti, A.; Faccoli, M. Climate affects severity and altitudinal distribution of outbreaks in an eruptive bark beetle. Clim. Chang. 2012, 115, 327-341. [CrossRef]

104. Raffa, K.F.; Aukema, B.H.; Bentz, B.J.; Carroll, A.L.; Hicke, J.A.; Kolb, T.E.; Björkman, C.; Niemelä, P. Responses of tree-killing bark beetles to a changing climate. In Climate Change and Insect Pests; CABI: Warszawa, Poland, 2015; pp. 173-201. ISBN 9781780643786.

105. Starzyk, J.R. Species characteristics (Charakterystyka gatunku). In The bark beetle and its role in forest ecosystems (Kornik drukarz i jego rola w ekosystemach leśnych); Grodzki, W., Ed.; CILP: Warszawa, Poland, 2013; pp. 99-103. ISBN 978-83-63895-08-2.

106. Brzeziecki, B.; Hilszczański, J.; Kowalski, T.; Łakomy, P.; Małek, S.; Miścicki, S.; Modrzyński, J.; Sowa, J.; Starzyk, J.R. The problem of mortality of spruce stands in the "Puszcza Białowieska" Leśny Kompleks Promocyjny (Problem masowego zamierania drzewostanów świerkowych w Leśnym Kompleksie Promocyjnym "Puszcza Białowieska"). Sylwan 2018, 162.

107. Starzyk, J.R. Abiotic and anthropogenic factors (Czynniki abiotyczne i antropogeniczne). In The Bark Beetle and its Role in Forest Ecosystems (Kornik drukarz i jego rola w ekosystemach leśnych); Grodzki, W., Ed.; CILP: Warszawa, Poland, 2013; pp. 99-103. ISBN 978-83-63895-08-2.

108. Virtanen, T.; Neuvonen, S.; Nikula, A.; Varama, M.; Niemelä, P. Climate change and the risks of Neodiprion sertifer outbreaks on Scots pine. Silva. Fenn. 1996, 30, 169-177. [CrossRef]

109. Ramsfield, T.; Bentz, B.; Faccoli, M.; Jactel, H.; Brockerhoff, E.G. Forest health in a changing world: Effects of globalization and climate change on forest insect and pathogen impacts. Forests 2016, 89, 245-252. [CrossRef]

110. Jaworski, J.; Hilszczański, T. Impact of temperature and humidity changes on development cycles and the importance of insects in forest ecosystems in connection with probable climate changes. (Wpływ zmian temperatury i wilgotności na cykle rozwojowe i znaczenie owadów w ekosystemach leśnych w związku z prawdopodobnymi zmianami klimatycznymi). For. Res. Pap. 2013, 74, 345-355. [CrossRef]

111. Hódar, J.A.; Zamora, R. Herbivory and climatic warming: A Mediterranean outbreaking caterpillar attacks a relict, boreal pine species. Biodivers. Conserv. 2004, 13, 493-500. [CrossRef] 
112. Dickie, I.A.; Bufford, J.L.; Cobb, R.C.; Desprez-Loustau, M.-L.; Grelet, G.; Hulme, P.E.; Klironomos, J.; Makiola, A.; Nuñez, M.A.; Pringle, A.; et al. The emerging science of linked plant-fungal invasions. New Phytol. 2017, 215, 1314-1332. [CrossRef]

113. Britton, K.O.; Liebhold, A.M. One world, many pathogens! New Phytol. 2013, 197, 9-10. [CrossRef]

114. Lonsdale, D. Review of oak mildew, with particular reference to mature and veteran trees in Britain. Arboric. J. 2015, 37, 61-84. [CrossRef]

115. Guo, C.; Xu, J.; Yang, L.; Guo, X.; Liao, J.; Zheng, X.; Zhang, Z.; Chen, X.; Yang, K.; Wang, M. Life cycle evaluation of greenhouse gas emissions of a highway tunnel: A case study in China. J. Clean. Prod. 2019, 211, 972-980. [CrossRef]

116. Marçais, B.; Desprez-Loustau, M.L. European oak powdery mildew: Impact on trees, effects of environmental factors, and potential effects of climate change. Ann. For. Sci. 2014, 71, 633-642. [CrossRef]

117. Jarvis, W.R.; Gubler, W.D.; Grove, G.G. Epidemiology of powdery mildews in agricultural pathosystems. In The Powdery Mildews, A Comprehensive Treatise; Bélanger, R.R., Bushnell, W.R., Dik, A.J., Carver, T.L.W., Eds.; APS Press: St. Paul, MI, USA, 2002; pp. 169-199.

118. Asher, M.J.C.; Williams, G.E. Forecasting the national incidence of sugar-beet powdery mildew from weather data in Britain. Plant Pathol. 1991, 40, 100-107. [CrossRef]

119. Mmbaga, M.T. Ascocarp formation and survival and primary inoculum production in Erysiphe (sect. Microsphaera) pulchra in dogwood powdery mildew. Ann. Appl. Boil. 2002, 141, 153-161. [CrossRef]

120. Penczykowski, R.M.; Walker, E.; Soubeyrand, S.; Laine, A.L. Linking winter conditions to regional disease dynamics in a wild plant-pathogen metapopulation. New Phytol. 2015, 205, 1142-1152. [CrossRef]

121. Camenen, E.; Porté, A.J.; Garzón, M.B. American trees shift their niches when invading Western Europe: Evaluating invasion risks in a changing climate. Ecol. Evol. 2016, 6, 7263-7275. [CrossRef]

122. Johnsen, O.; Daehlen, O.G.; Østreng, G.; Skrøppa, T.; Dæhlen, O.G. Daylength and temperature during seed production interactively affect adaptive performance of Picea abies progenies. New Phytol. 2005, 168, 589-596. [CrossRef] [PubMed]

123. Caignard, T.; Kremer, A.; Firmat, C.; Nicolas, M.; Venner, S.; Delzon, S. Increasing spring temperatures favor oak seed production in temperate areas. Sci. Rep. 2017, 7, 8555. [CrossRef]

124. Rossi, S. Local adaptations and climate change: Converging sensitivity of bud break in black spruce provenances. Int. J. Biometeorol. 2015, 59, 827-835. [CrossRef]

125. Ford, K.R.; Harrington, C.A.; Bansal, S.; Gould, P.J.; Clair, J.B.S. Will changes in phenology track climate change? A study of growth initiation timing in coast Douglas-fir. Glob. Chang. Boil. 2016, 22, 3712-3723. [CrossRef] [PubMed]

126. Lankau, R.A.; Zhu, K.; Ordonez, A. Mycorrhizal strategies of tree species correlate with trailing range edge responses to current and past climate change. Ecology 2015, 96, 1451-1458. [CrossRef]

127. Lau, J.A.; Lennon, J.T.; Heath, K.D. Trees harness the power of microbes to survive climate change. Proc. Natl. Acad. Sci. USA 2017, 114, 11009-11011. [CrossRef] [PubMed]

128. Cavin, L.; Jump, A.S. Highest drought sensitivity and lowest resistance to growth suppression are found in the range core of the tree Fagus sylvatica L. not the equatorial range edge. Glob. Chang. Boil. 2016, 23, 362-379. [CrossRef]

129. Savi, T.; Bertuzzi, S.; Branca, S.; Tretiach, M.; Nardini, A. Drought-induced xylem cavitation and hydraulic detorientation: Risk factors for urban trees under climate change? New Phytol. 2015, 205, 1106-1116. [CrossRef]

130. Pretzsch, H.; Biber, P.; Uhl, E.; Dahlhausen, J.; Schütze, G.; Perkins, D.; Rötzer, T.; Caldentey, J.; Koike, T.; Van Con, T.; et al. Climate change accelerates growth of urban trees in metropolises worldwide. Sci. Rep. 2017, 7, 15403. [CrossRef]

131. Medlyn, B.E.; Dreyer, E.; Ellsworth, D.; Forstreuter, M.; Harley, P.C.; Kirschbaum, M.U.F.; Le Roux, X.; Montpied, P.; Strassemeyer, J.; Walcroft, A.; et al. Temperature response of parameters of a biochemically based model of photosynthesis. II. A review of experimental data. Plant Cell Environ. 2002, 25, 253-264. [CrossRef]

132. De Kort, H.; Vander Mijnsbrugge, K.; Vandepitte, K.; Mergeay, J.; Ovaskainen, O.; Honnay, O. Evolution, plasticity and evolving plasticity of phenology in the tree species Alnus glutinosa. J. Evol. Biol. 2016, 29, 253-264. [CrossRef] 
133. Jump, A.S.; Peñuelas, J. Running to stand still: Adaptation and the response of plants to rapid climate change. Ecol. Lett. 2005, 8, 1010-1020. [CrossRef]

134. Williams, B.L.; Brawn, J.D.; Paige, K.N. Landscape scale genetic effects of habitat fragmentation on a high gene flow species: Speyeria idalia (Nymphalidae). Mol. Ecol. 2003, 12, 11-20. [CrossRef]

135. Gutschick, V.P.; BassiriRad, H. Extreme events as shaping physiology, ecology, and evolution of plants: Toward a unified definition and evaluation of their consequences. New Phytol. 2003, 160, 21-42. [CrossRef]

136. DeWitt, T.J.; Sih, A.; Wilson, D.S. Costs and limits of phenotypic plasticity. Trends Ecol. Evol. 1998, 13, 77-81. [CrossRef]

137. Peñuelas, J.; Lloret, F.; Montoya, R. Severe drought effects on Mediterranean woody flora in Spain. For. Sci. 2001, 47, 214-218. [CrossRef]

138. Peñuelas, J.; Boada, M. A global change-induced biome shift in the Montseny mountains (NE Spain). Glob. Chang. Boil. 2003, 9, 131-140. [CrossRef]

139. Walther, G.R. Plants in a warmer world. In Perspectives in Plant Ecology, Evolution and Systematics; Edwards, P., Ed.; Stockton Press: Jena, Germany, 2003; Volume 6, pp. 169-185. ISBN 14338319.

140. Pliūra, A.; Jankauskienè, J.; Bajerkevičienè, G.; Lygis, V.; Suchockas, V.; Labokas, J.; Verbylaitè, R. Response of juveniles of seven forest tree species and their populations to different combinations of simulated climate change-related stressors: Spring-frost, heat, drought, increased UV radiation and ozone concentration under elevated $\mathrm{CO}_{2}$ level. J. Plant Res. 2019, 132, 789-811. [CrossRef]

141. De Jong, G. Evolution of phenotypic plasticity: Patterns of plasticity and the emergence of ecotypes. New Phytol. 2005, 166, 101-118. [CrossRef]

142. Dobrowolska, D. Vitality of European Beech (Fagus sylvatica L.) at the Limit of Its Natural Range in Poland. Pol. J. Ecol. 2015, 63, 260-272. [CrossRef]

143. Arana, M.V.; Gonzalez-Polo, M.; Martinez-Meier, A.; Gallo, L.A.; Benech-Arnold, R.L.; Sánchez, R.A.; Batlla, D. Seed dormancy responses to temperature relate to Nothofagus species distribution and determine temporal patterns of germination across altitudes in Patagonia. New Phytol. 2016, 209, 507-520. [CrossRef]

144. Walck, J.L.; Hidayati, S.N.; Dixon, K.W.; Thompson, K.; Poschlod, P. Climate change and plant regeneration from seed. Glob. Chang. Boil. 2011, 17, 2145-2161. [CrossRef]

145. O'Sullivan, O.S.; Heskel, M.A.; Reich, P.B.; Tjoelker, M.G.; Weerasinghe, L.K.; Penillard, A.; Zhu, L.; Egerton, J.J.G.; Bloomfield, K.J.; Creek, D.; et al. Thermal limits of leaf metabolism across biomes. Glob. Chang. Boil. 2016, 23, 209-223. [CrossRef]

146. Baskin, J.M.; Baskin, C.C. Seed germination ecophysiology of jeffersonia diphylla, a perennial herb of mesic deciduous forests. Am. J. Bot. 1989, 76, 1073-1080. [CrossRef]

147. Jansen, P.A.; Bongers, F.; Hemerik, L. Seed mass and mast seeding enhance dispersal by a neotropical scatter-hoarding rodent. Ecol. Monogr. 2004, 74, 569-589. [CrossRef]

148. Gómez, J.M. Bigger is not always better: Conflicting selective pressures on seed size in quercus ILEX. Evolution 2004, 58, 71-80. [CrossRef] [PubMed]

149. Davis, C.C.; Willis, C.G.; Primack, R.B.; Miller-Rushing, A.J. The importance of phylogeny to the study of phenological response to global climate change. Philos. Trans. R. Soc. B Boil. Sci. 2010, 365, 3201-3213. [CrossRef]

150. Carta, A.; Hanson, S.; Müller, J.V. Plant regeneration from seeds responds to phylogenetic relatedness and local adaptation in Mediterranean Romulea (Iridaceae) species. Ecol. Evol. 2016, 6, 4166-4178. [CrossRef]

151. Willis, C.G.; Ruhfel, B.; Primack, R.B.; Miller-Rushing, A.J.; Davis, C.C. Phylogenetic patterns of species loss in Thoreau's woods are driven by climate change. Proc. Natl. Acad. Sci. USA 2008, 105, 17029-17033. [CrossRef]

152. Davies, T.J.; Wolkovich, E.M.; Kraft, N.J.B.; Salamin, N.; Allen, J.M.; Ault, T.R.; Betancourt, J.L.; Bolmgren, K.; Cleland, E.E.; Cook, B.I.; et al. Phylogenetic conservatism in plant phenology. J. Ecol. 2013, 101, 1520-1530. [CrossRef]

153. Richardson, B.A.; Chaney, L.; Shaw, N.L.; Still, S.M. Will phenotypic plasticity affecting flowering phenology keep pace with climate change? Glob. Change Biol. 2017, 23, 2499-2508. [CrossRef]

154. Levin, N.A. Flowering Phenology in Relation to Adaptive Radiation. Syst. Bot. 2006, 31, 239-246. [CrossRef]

155. De Casas, R.R.; Kovach, K.; Dittmar, E.; Barua, D.; Barco, B.; Donohue, K. Seed after-ripening and dormancy determine adult life history independently of germination timing. New Phytol. 2012, 194, 868-879. [CrossRef] 
156. Elwell, A.L.; Gronwall, D.S.; Miller, N.D.; Spalding, E.P.; Durham Brooks, T.L. Separating parental environment from seed size effects on next generation growth and development in Arabidopsis. Plant Cell Environ. 2011, 34, 291-301. [CrossRef]

157. Billington, H.L.; Pelham, J. Genetic Variation in the Date of Budburst in Scottish Birch Populations: Implications for Climate Change. Funct. Ecol. 1991, 5, 403. [CrossRef]

158. Dahlquist, R.M.; Prather, T.S.; Stapleton, J.J. Time and Temperature Requirements for Weed Seed Thermal Death. Weed Sci. 2007, 55, 619-625. [CrossRef]

159. Kim, D.H.; Han, S.H. Direct Effects on Seed Germination of 17 Tree Species under Elevated Temperature and $\mathrm{CO}_{2}$ Conditions. Open Life Sci. 2018, 13, 137-148. [CrossRef]

160. Peterson, M.E.; Daniel, R.M.; Danson, M.J.; Eisenthal, R. The dependence of enzyme activity on temperature: Determination and validation of parameters. Biochem. J. 2007, 402, 331-337. [CrossRef]

161. De Villalobos, A.; Pelaez, D.; Boo, R.; Mayor, M.; Elia, O. Effect of high temperatures on seed germination of Prosopis caldenia Burk. J. Arid. Environ. 2002, 52, 371-378. [CrossRef]

162. Harrington, C.A.; Gould, P.J.; St.Clair, J.B. Modeling the effects of winter environment on dormancy release of Douglas-fir. For. Ecol. Manag. 2010, 259, 798-808. [CrossRef]

163. Duputié, A.; Rutschmann, A.; Ronce, O.; Chuine, I. Phenological plasticity will not help all species adapt to climate change. Glob. Chang. Boil. 2015, 21, 3062-3073. [CrossRef]

164. Vegis, A. Dormancy in Higher Plants. Annu. Rev. Plant Physiol. 1964, 15, 185-224. [CrossRef]

165. Fu, Y.H.; Piao, S.; Vitasse, Y.; Zhao, H.; De Boeck, H.J.; Liu, Q.; Yang, H.; Weber, U.; Hänninen, H.; Janssens, I.A. Increased heat requirement for leaf flushing in temperate woody species over 1980-2012: Effects of chilling, precipitation and insolation. Glob. Chang. Boil. 2015, 21, 2687-2697. [CrossRef]

166. Hänninen, H.; Kramer, K. A framework for modelling the annual cycle of trees in boreal and temperate regions. Silva. Fenn. 2007, 41, 167-205. [CrossRef]

167. West-Eberhard, M.J. Toward a Modern Revival of Darwin's Theory of Evolutionary Novelty. Philos. Sci. 2008, 75, 899-908. [CrossRef]

168. Jump, A.S.; Marchant, R.; Peñuelas, J.; Marchant, R. Environmental change and the option value of genetic diversity. Trends Plant Sci. 2009, 14, 51-58. [CrossRef]

169. Nicotra, A.; Atkin, O.; Bonser, S.; Davidson, A.; Finnegan, E.J.; Mathesius, U.; Poot, P.; Purugganan, M.; Richards, C.; Valladares, F.; et al. Plant phenotypic plasticity in a changing climate. Trends Plant Sci. 2010, 15, 684-692. [CrossRef] [PubMed]

170. Lande, R. Adaptation to an extraordinary environment by evolution of phenotypic plasticity and genetic assimilation. J. Evol. Boil. 2009, 22, 1435-1446. [CrossRef] [PubMed]

171. Van Kleunen, M.; Fischer, M. Adaptive evolution of plastic foraging responses in a clonal plant. Ecology 2001, 82, 3309-3319. [CrossRef]

172. Van Kleunen, M.; Lenssen, J.P.M.; Fischer, M.; De Kroon, H. Selection on phenotypic plasticity of morphological traits in response to flooding and competition in the clonal shore plant Ranunculus reptans. J. Evol. Boil. 2007, 20, 2126-2137. [CrossRef] [PubMed]

173. Bräutigam, K.; Vining, K.J.; Lafon-Placette, C.; Fossdal, C.G.; Mirouze, M.; Marcos, J.G.; Fluch, S.; Fraga, M.F.; Guevara, M.; Ángeles, L.; et al. Epigenetic regulation of adaptive responses of forest tree species to the environment. Ecol. Evol. 2013, 3, 399-415. [CrossRef]

174. Zhang, Y.Y.; Fischer, M.; Colot, V.; Bossdorf, O. Epigenetic variation creates potential for evolution of plant phenotypic plasticity. New Phytol. 2013, 197, 314-322. [CrossRef]

175. Sow, M.D.; Segura, V.; Chamaillard, S.; Jorge, V.; Delaunay, A.; Lafon-Placette, C.; Fichot, R.; Faivre-Rampant, P.; Villar, M.; Brignolas, F.; et al. Narrow-sense heritability and PST estimates of DNA methylation in three Populus nigra L. populations under contrasting water availability. Tree Genet. Genomes 2018, 14, 78. [CrossRef]

176. Gourcilleau, D.; Bogeat-Triboulot, M.-B.; Thiec, D.; Lafon-Placette, C.; Delaunay, A.; Abu El-Soud, W.; Brignolas, F.; Maury, S. DNA methylation and histone acetylation: Genotypic variations in hybrid poplars, impact of water deficit and relationships with productivity. Ann. For. Sci. 2010, 67, 208. [CrossRef]

177. Le Gac, A.-L.; Lafon-Placette, C.; Chauveau, D.; Segura, V.; Delaunay, A.; Fichot, R.; Marron, N.; Le Jan, I.; Berthelot, A.; Bodineau, G.; et al. Winter-dormant shoot apical meristem in poplar trees shows environmental epigenetic memory. J. Exp. Bot. 2018, 69, 4821-4837. [CrossRef] 
178. Raj, S.; Bräutigam, K.; Hamanishi, E.T.; Wilkins, O.; Thomas, B.R.; Schroeder, W.; Mansfield, S.D.; Plant, A.L.; Campbell, M.M. Clone history shapes Populus drought responses. Proc. Natl. Acad. Sci. USA 2011, 108, 12521-12526. [CrossRef] [PubMed]

179. Lafon-Placette, C.; Faivre-Rampant, P.; Delaunay, A.; Street, N.; Brignolas, F.; Maury, S. Methylome of DN ase I sensitive chromatin in Populus trichocarpa shoot apical meristematic cells: A simplified approach revealing characteristics of gene-body DNA methylation in open chromatin state. New Phytol. 2013, 197, 416-430. [CrossRef]

180. Bossdorf, O.; Richards, C.L.; Pigliucci, M. Epigenetics for ecologists. Ecol Lett. 2008, 11, 106-115. [CrossRef] [PubMed]

181. Sáez-Laguna, E.; Guevara, M.-A.; Díaz, L.-M.; Sánchez-Gómez, D.; Collada, C.; Aranda, I.; Cervera, M.-T. Epigenetic Variability in the Genetically Uniform Forest Tree Species Pinus pinea L. PLoS ONE 2014, 9, e103145. [CrossRef]

182. Skrøppa, T.; Johnsen, Ø. Patterns of adaptive genetic variation in forest tree species; the reproductive enviroment as an evolutionary force in Picea abies. Agrofor. Sci. Policy Pract. 2000, 63, 49-58.

183. Skrøppa, T.; Tollefsrud, M.M.; Sperisen, C.; Johnsen, $\varnothing$. Rapid change in adaptive performance from one generation to the next in Picea abies-Central European trees in a Nordic environment. Tree Genet.Genomes 2010, 6, 93-99. [CrossRef]

184. Ashcroft, M.B.; Gollan, J.R.; Batley, M. Combining citizen science, bioclimatic envelope models and observed habitat preferences to determine the distribution of an inconspicuous, recently detected introduced bee (Halictus smaragdulus Vachal Hymenoptera: Halictidae) in Australia. Biol. Invasions 2012, 14, 515-527. [CrossRef]

185. Deb, J.C.; Phinn, S.; Butt, N.; McAlpine, C.A. The impact of climate change on the distribution of two threatened Dipterocarp trees. Ecol. Evol. 2017, 7, 2238-2248. [CrossRef]

186. Hanewinkel, M.; Cullmann, D.A.; Schelhaas, M.-J.; Nabuurs, G.-J.; Zimmermann, N.E. Climate change may cause severe loss in the economic value of European forest land. Nat. Clim. Chang. 2013, 3, $203-207$. [CrossRef]

187. Leech, S.M.; Almuedo, P.L.; O'Neill, G. Assisted migration: Adapting forest management to a changing climate. J. Ecol. Manag. 2011, 12, 18-34.

188. Dumroese, R.K.; Williams, M.I.; Stanturf, J.A.; Clair, J.B.S. Considerations for restoring temperate forests of tomorrow: Forest restoration, assisted migration, and bioengineering. New For. 2015, 46, 947-964. [CrossRef]

189. Erickson, V.; Aubry, C.; Berrang, P.; Blush, T.; Bower, A.; Crane, B.; Johnson, R. Genetic Resource Management and Climate Change: Genetic Options for Adapting National Forests to Climate Change; USDA Forest Service Forest Management: Washington, DC, USA, 2012.

190. Grady, K.C.; Kolb, T.E.; Ikeda, D.H.; Whitham, T.G. A bridge too far: Cold and pathogen constraints to assisted migration of riparian forests. Restor. Ecol. 2015, 23, 811-820. [CrossRef]

191. O’Neill, G.A.; Ukrainetz, N.K.; Carlson, M.R.; Cartwright, C.V.; Jaquish, B.C.; King, J.N.; Krakowski, J.; Russell, J.H.; Stoehr, M.; Xie, C.Y.; et al. Assisted Migration to Address Climate Change in British Columbia: Recommendations for Interim Seed Transfer Standards; BC Ministry of Forests and Range, Forest Sci Branch: Victoria, BC, Canada, 2008; Tech Rep. 048; ISBN 978-0-7726-6076-3.

192. St.Clair, J.B.; Howe, G.T. Strategies for conserving forest genetic resources in the face of climate change. Turk. J. Bot. 2011, 35, 403-409. [CrossRef]

193. Keppel, G.; Van Niel, K.P.; Wardell-Johnson, G.W.; Yates, C.J.; Byrne, M.; Mucina, L.; Schut, A.G.T.; Hopper, S.D.; Franklin, S.E. Refugia: Identifying and understanding safe havens for biodiversity under climate change. Glob. Ecol. Biogeogr. 2012, 21, 393-404. [CrossRef]

(C) 2020 by the authors. Licensee MDPI, Basel, Switzerland. This article is an open access article distributed under the terms and conditions of the Creative Commons Attribution (CC BY) license (http://creativecommons.org/licenses/by/4.0/). 